\title{
3. RADIOLARIAN BIOSTRATIGRAPHY OF SITES 902, 903, AND 904
}

\author{
Catherine Nigrini ${ }^{2}$
}

\begin{abstract}
The radiolarian fauna found at three sites drilled on the New Jersey continental slope range in age from late Oligocene to middle Miocene. The fauna is never abundant and is only poorly to moderately well preserved. Detailed range charts as well as a listing of stratigraphically significant radiolarian events (morphotypic first and last occurrences) are given for the three sites. Absolute ages, determined from strontium isotope analyses of mixed foraminifer species, combined with the stratigraphic ranges of the fauna provide new data concerning the age of radiolarian events in this part of the world ocean. Most of the calculated age ranges are synchronous with those derived in other areas, but three events show significant diachrony. One new taxon is described and illustrated but not named.
\end{abstract}

\section{INTRODUCTION}

Radiolarians were studied from the upper Oligocene and lower and middle Miocene intervals of three sites occupied during Leg 150 of the Ocean Drilling Program. All three sites were drilled on the New Jersey continental slope (Fig. 1). In general, the radiolarian fauna is not abundant, and preservation varies between moderate and poor. Sample cleaning proved to be difficult and taxa are frequently obscured by clay aggregates or overwhelmed by mineral fragments and/or diatoms. Hole $904 \mathrm{~A}$ provides the best record; Hole 902D contains the poorest. Locations and water depths of the three sites are as follows:

\begin{tabular}{ccc}
\hline Site & Location & $\begin{array}{c}\text { Water depth } \\
(\mathrm{m})\end{array}$ \\
\hline 902 & $38^{\circ} 56.080^{\prime} \mathrm{N} 72^{\circ} 46.348^{\prime} \mathrm{W}$ & 815.0 \\
903 & $38^{\circ} 56.298^{\prime} \mathrm{N} 72^{\circ} 49.032^{\prime} \mathrm{W}$ & 444.4 \\
904 & $38^{\circ} 51.806^{\prime} \mathrm{N} 72^{\circ} 46.084^{\prime} \mathrm{W}$ & 1122.8 \\
\hline
\end{tabular}

\section{METHODS}

One $5-\mathrm{cm}^{3}$ sample per core was taken from Hole $902 \mathrm{D}$ and from a composite of Holes 903C and 903D. For Hole 904A, three samples per core were taken, generally from Sections 2, 4, and 6. Sample preparation first followed the standard techniques described by Sanfilippo et al. (1985). In addition, to further disaggregate the clay content, samples were placed for several hours in a $5 \%$ ammonia solution. For each sample examined, qualitative estimates of radiolarian abundance were made and recorded as follows: $\mathrm{C}=$ common (100 to 500 specimens on slide); $\mathrm{F}=$ few ( 50 to 100 specimens on slide); $\mathrm{R}$ $=$ rare $(<50$ specimens on slide $) ; \mathrm{vR}=$ very rare $(<10$ specimens on slide). Preservation of the radiolarian assemblage was judged as follows: $\mathrm{G}$ (good) = no signs of dissolution of the taxa present and only minor fragmentation; $M$ (moderate) = some evidence of dissolution and obvious fragmentation; $\mathrm{P}$ (poor) = high degree of dissolution with many broken specimens. It should be noted, however, that in these assemblages delicate forms were never observed, indicating either dissolution of delicate structures or absence of delicate forms at these latitudes. Range charts based on presence or absence $(\mathrm{P}=$ present; += one or two specimens; $-=$ searched for and not found; ?

Mountain, G.S., Miller, K.G., Blum, P., Poag, C.W., and Twichell, D.C. (Eds.), 1996. Proc. ODP, Sci. Results, 150: College Station, TX (Ocean Drilling Program).

${ }_{2510}$ Papyrus Drive, La Habra Heights, CA 90631, U.S.A. nigrini@chelsea.ios.com

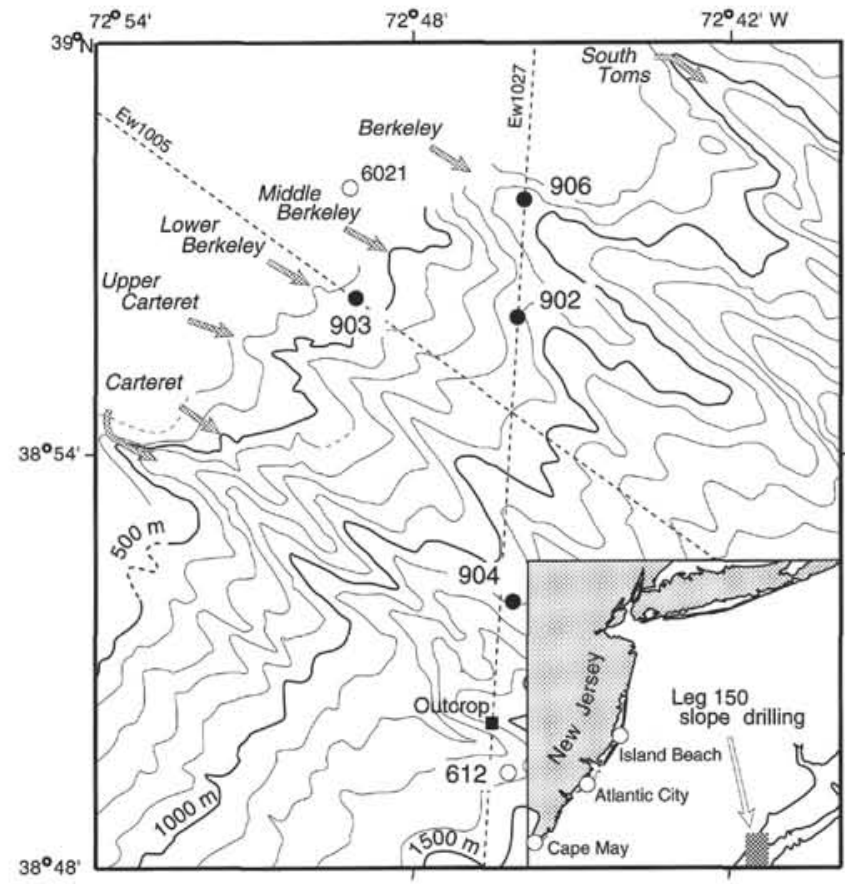

Figure 1. SeaBeam bathymetric location map of the middle continental slope (500-1500 m water depth) drilled during Leg 150 showing Sites 902, 903, 904, 906, and DSDP Site 612 .

= dubious identification) of stratigraphically important taxa were constructed for the upper Oligocene to middle Miocene interval at each site (Tables 1-3).

\section{Stratigraphy}

For the most part it was possible to apply the tropical radiolarian zonation of Riedel and Sanfilippo $(1971,1978)$ to the sections studied. Sanfilippo and Nigrini's (1995) modification of placement of the Oligocene/Miocene boundary in relation to radiolarian events was followed. According to them, the epoch boundary lies between the last occurrence of Artophormis gracilis and the first occurrence of Cyrtocapsella tetrapera. Although some zonal marker species, particularly in the lower Miocene, are absent, it has been possible to rec- 
Table 1. Range chart for strigraphically important radiolarian species in Hole 902D.

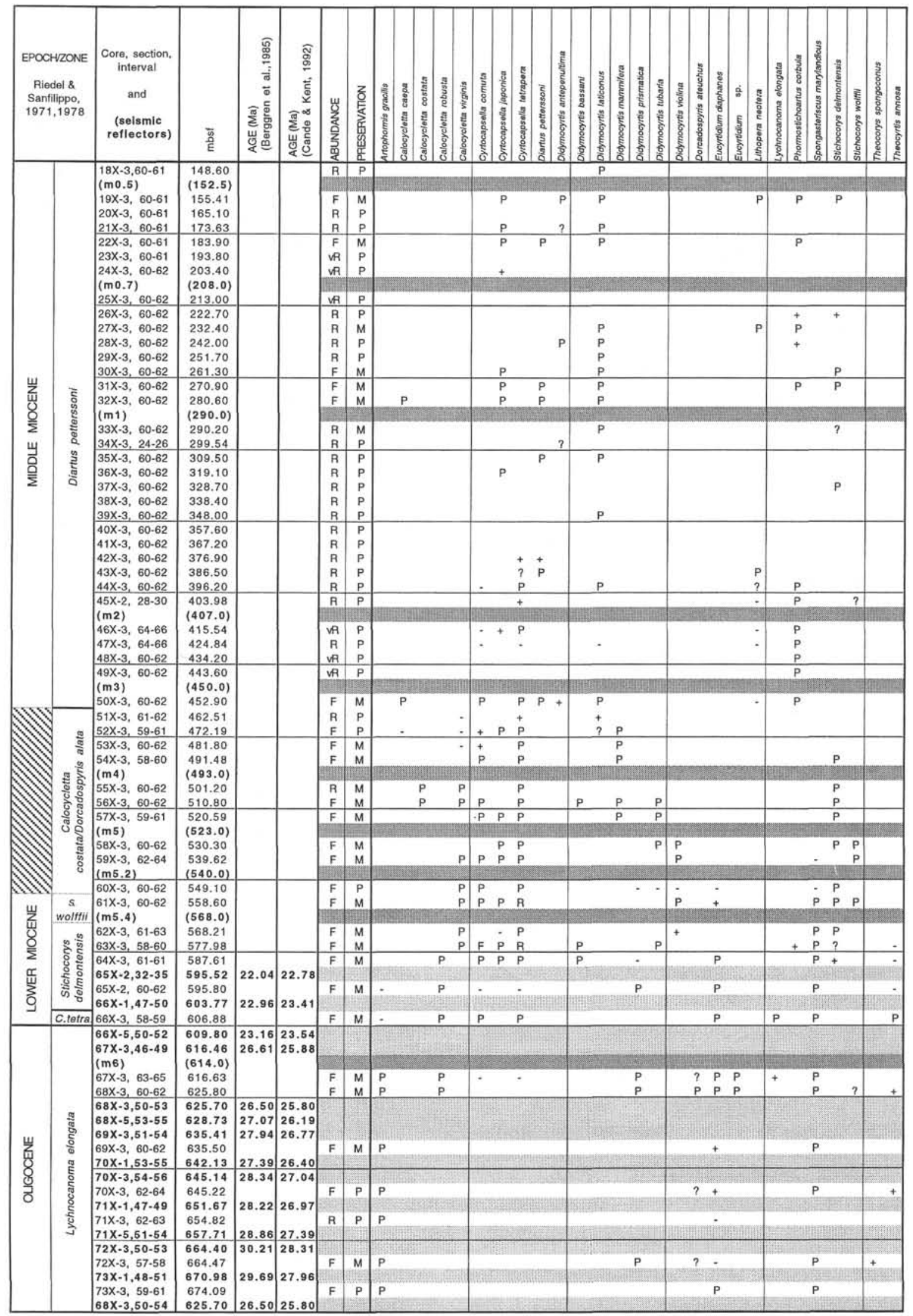

Notes: Dark shading indicates stratigraphic position of seismic reflectors; light shading indicates stratigraphic position of strontium isotope analyses. For explanation of symbols, see "Methods" section. 
Table 2. Range chart for stratigraphically important radiolarian species in Holes 903C/D.

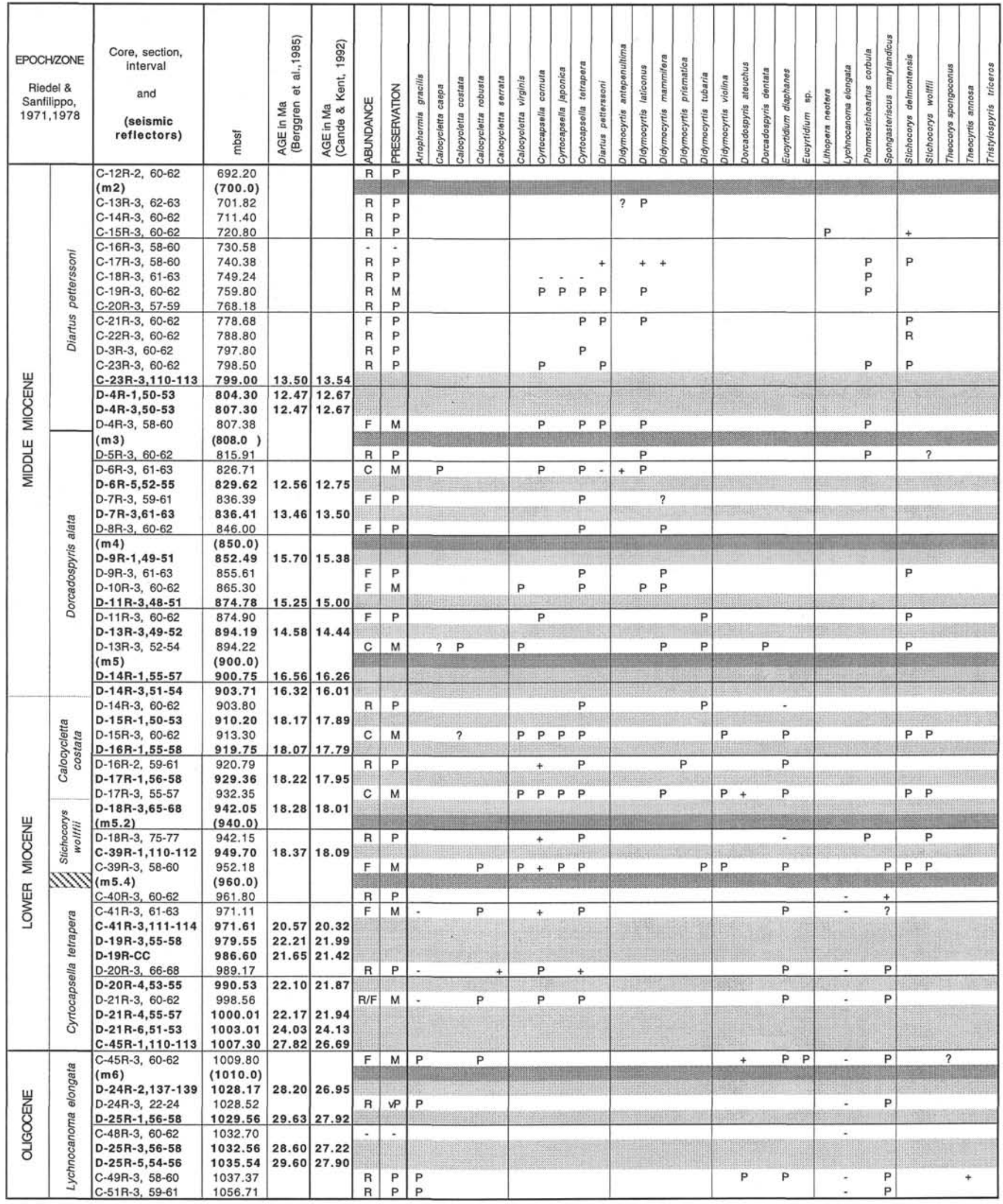

Notes: See Table 1. 
Table 3. Range chart for stratigraphically important radiolarian species in Hole 904A.

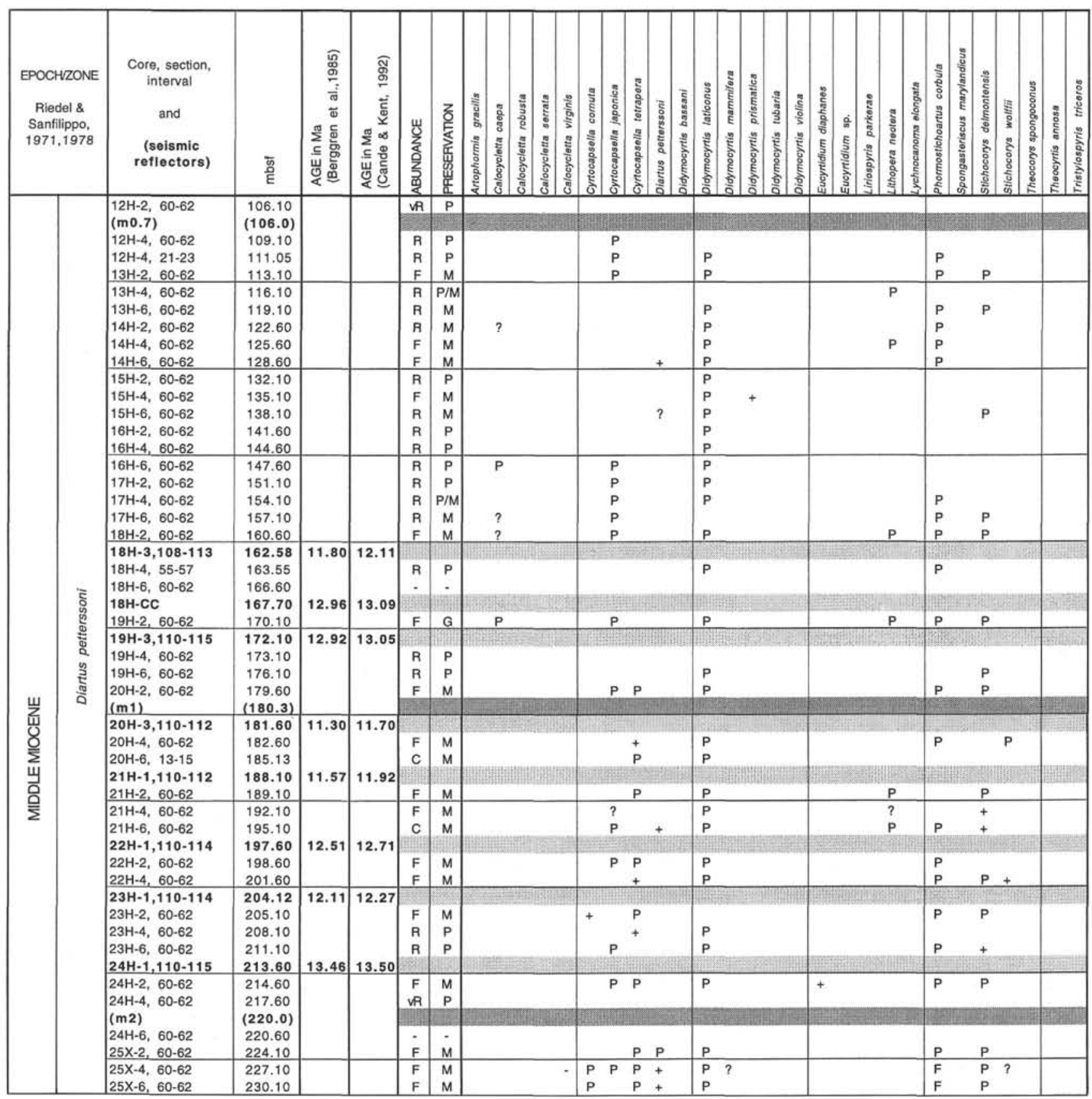

Notes: See Table 1.

ognize most of the tropical zones from the Lychnocanoma elongata Zone in the upper Oligocene to the Diartus petterssoni Zone in the middle Miocene. However, the boundaries between some zones are not always precise. Zonal assignments have assumed that radiolarian events on the New Jersey Margin are synchronous with those recorded in tropical sediments (but see "Comparison of Radiolarian Events" section for notable exceptions). Stratigraphic determinations have been aided by the identification of seismic reflectors (Mountain et al., this volume) and age data derived from analysis of mixed foraminifer species for $\mathrm{Sr}$ isotopes (Miller et al., this volume) at all three sites.

\section{RADIOLARIANS AT EACH SITE}

\section{Hole 902D}

Site 902 was drilled on the New Jersey continental margin $145 \mathrm{~km}$ east-southeast of Barnegat Inlet, New Jersey, in a region of steeply sloping topography and incised slope canyons. One sample per core from Core 150-902D-18X through Core 150-902D-73X was examined for radiolarians. This interval ranges from upper Oligocene to middle Miocene. Abundance and preservation of taxa are relatively 
Table 3 (continued).

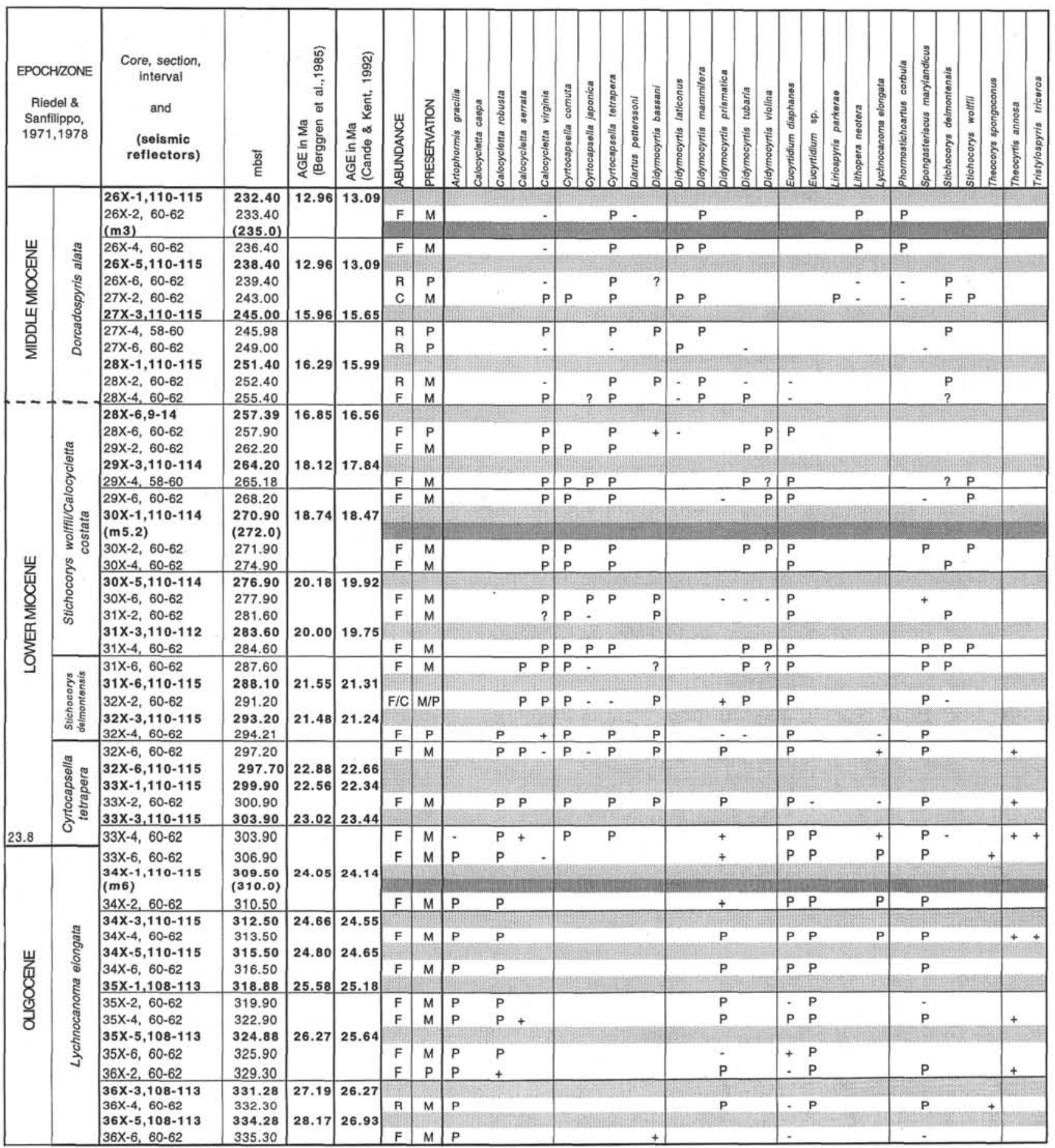

good below Core 150-902D-50X and generally poor above that level. Age data derived from 15 strontium isotope analyses are available from Core 150-902D-65X through Core 150-902D-73X, and 10 seismic reflectors have been recognized in the examined interval (Table 1).

The base of the $D$. antepenultima Zone is closely allied to the evolutionary transition from Didymocyrtis laticonus to $D$. antepenulti$m a$. Although rare specimens of the descendant form were found in the upper samples examined from Hole 902D, it is never dominant, and so we must assume that Sample 150-902D-18X-3, 60-61 cm
( $148.60 \mathrm{mbsf}$ ), is still within the Diartus petterssoni Zone and is middle Miocene. The base of the $D$. petterssoni Zone, defined by the first morphotypic occurrence of $D$. petterssoni, can be placed between Samples 150-902D-50X-3, 60-62 cm (452.0 mbsf), and 150-902D$51 X-3,61-62 \mathrm{~cm}$ (462.51 mbsf). Because of the absence of zonal marker species, the boundaries between the lower Miocene zones Dorcadospyris alata, Calocycletta costata, and Stichocorys wolffii could not be recognized with any certainty. However, some events within the zones indicate an appropriate zonal assignment for particular pairs of samples. For example, the upper limit of Didymocyrtis 
mammifera is known to occur within the $D$. alata Zone, and, therefore, Samples 150-902D-51X-3, 59-61 cm (462.51 mbsf), and 150902D-52X-3, 59-61 cm (472.19 mbsf), between which this event occurs, can probably be assigned to the $D$, alata Zone. Similar arguments have been applied in the placement of these boundaries on all range charts in which the zonal markers are missing. Unfortunately, this approach in Hole 902D gives some mixed signals, and the $D$. alata and $C$. costata Zones cannot be distinguished. Because the lower to middle Miocene boundary lies at the base of the $D$. alata Zone, it cannot be placed precisely in Hole 902D. The base of the $S$. wolffii Zone, defined by the first occurrence of $S$. wolffii, apparently occurs between Samples 150-902D-61X-3, 60-62 cm (558.60 mbsf), and $150-902 \mathrm{D}-62 \mathrm{X}-3,61-63 \mathrm{~cm}$ (558.60 mbsf), but the first occurrence of Didymocyrtis violina in Sample 150-902D-62X-3, 61-63 cm, places this sample in the Stichocorys delmontensis Zone. Hence, there appears to be a hiatus at this level, and the lower part of the $S$. wolffii Zone and/or the upper part of the $S$. delmontensis Zone is missing. Rare occurrences of Theocyrtis annosa suggest that the lower limit of the $S$. delmontensis Zone lies between Samples 150-902D$65 \mathrm{X}-2,60-62 \mathrm{~cm}$ (595.80 mbsf), and 150-902D-66X-3, 58-59 cm ( $606.88 \mathrm{mbsf})$. Several events associated with the Oligocene/Miocene boundary occur between Samples 150-902D-66X-3, 58-59 cm (606.88 mbsf), and 150-902D-67X-3, 63-65 cm (616.63 mbsf), suggesting a hiatus, which can also be correlated with Reflector m6 (pink-3), between these samples. The remaining examined interval lies within the $L$. elongata Zone.

\section{Holes 903C and 903D}

Site 903 was drilled on the New Jersey continental slope $4.4 \mathrm{~km}$ upslope of Site 902 and is located $141 \mathrm{~km}$ east-southeast of Barnegat Inlet, New Jersey. Samples from Holes 903C and 903D have been interleaved to obtain a complete section ranging from upper Oligocene to middle Miocene. Abundance and preservation are relatively good between Cores 150-903D-4R and 150-903C-45R, but are poor above and below this interval. Age data derived from 27 strontium isotope analyses are available from Core 150-903C-23R through Core 150903D-25R, and seven seismic reflectors have been recognized in the examined interval (Table 2).

The base of the middle Miocene $D$. petterssoni Zone occurs between Samples 150-903D-4R, 58-60 cm (807.38 mbsf), and 150903D-5R-3, 60-62 cm (815.91 mbsf). As in Hole 902D, zonal marker species for the lower Miocene zones D. alata, $C$. costata, and $S$. wolffii are absent, but other radiolarian events within the zones aid in placement of certain sample pairs in particular zones. The last occurrence of both $D$. violina and Eucyrtidium diaphanes is located between Samples 150-903D-14R-3, 60-62 cm (903.8 mbsf), and 150903D-15R-3, 60-62 cm ( $913.30 \mathrm{mbsf})$. Because the last occurrence of $D$. violina usually occurs in the $D$. alata Zone and the last occurrence of $E$. diaphanes usually occurs in the $C$. costata Zone, the zonal boundary has been tentatively placed at this level, but their co-occurrence suggests that there is a hiatus at this level. The base of the $S$. wolffii Zone, which is defined by the first occurrence of $S$. wolffii, appears to be between Samples 150-903C-39R-3, 58-60 cm $(952.18$ mbsf), and 150-903C-40R-3, 60-62 cm (961.80 mbsf), but the concomitant first appearance of $S$. delmontensis at this level suggests that there is also some missing section at this level. The absence of $T$. annosa prevents recognition of the base of the $S$. delmontensis Zone, but the first occurrences of $C$. tetrapera and Cyrtocapsella cornuta in Sample 150-903D-21R-3, 60-62 cm (998.56 mbsf), places this sample in the $C$. tetrapera Zone. The last occurrences of A. gracilis and of Eucyrtidium sp. are also at this level. Co-occurrence of these four events supports evidence from both nannofossil and $\mathrm{Sr}$ isotope stratigraphy that there is a hiatus, coincident with seismic Reflector $\mathrm{m} 6$ (pink-3) at this level. Samples below 150-903C-45R-3, 60-62 cm (1009.80 mbsf), lie within the L. elongata Zone.

\section{Hole 904A}

Site 904 was drilled on the New Jersey continental slope $7.8 \mathrm{~km}$ downslope of Site 902 and $4.9 \mathrm{~km}$ upslope of Deep Sea Drilling Project (DSDP) Site 612 . It is $141 \mathrm{~km}$ east-southeast of Barnegat Inlet, New Jersey. Three samples per core were examined from the interval between Core 150-904A-12H and Core 150-904A-36X. No age determination based on radiolarians could be made for the interval above Core 150-904A-15H-6. Sample 150-904A-12H-2 is middle Miocene as far as one can tell from the taxa present and the oldest sample examined is upper Oligocene. Age data derived from 29 strontium isotope analyses are available from Core $150-904 \mathrm{~A}-18 \mathrm{H}$ through Core 150-904A-36X, and five seismic reflectors have been recognized in the examined interval (Table 3). Of the three sites examined for this report, Hole $904 \mathrm{~A}$ contains the most complete sequence of radiolarian events.

Planktonic foraminifers and nannofossils indicate that sediments above Reflector $\mathrm{ml}$ (Tuscan) are late Miocene ( $8 \mathrm{Ma})$ in age, whereas shipboard diatom and dinocyst interpretations place Cores 150-904A-19X and 150-904A-18X, at least, in the middle Miocene. There is no radiolarian evidence to suggest that sediments above $\mathrm{Re}$ flector $\mathrm{ml}$ (Tuscan) are upper Miocene, but the fauna is generally impoverished. The base of the middle Miocene $D$. petterssoni Zone occurs between Samples 150-904A-25X-6, 60-62 cm (230.10 mbsf), and $150-904 \mathrm{~A}-26 \mathrm{X}-2,60-62 \mathrm{~cm}(233.40 \mathrm{mbsf})$. Although the zonal marker species are missing, it appears that the interval between Samples 150-904A-26X-2, 60-62 cm (233.40 mbsf), and 150-904A$28 \mathrm{X}-4,60-62 \mathrm{~cm}$ ( $255.40 \mathrm{mbsf})$, belongs to the $D$. alata Zone. The base of this zone is considered to be coincident with the lower to middle Miocene boundary. The base of the $S$. wolffii Zone is between Samples 150-904A-31X-4, 60-62 cm (284.60 mbsf), and 150-904A$31 X-6,60-62 \mathrm{~cm}$ ( $287.60 \mathrm{mbsf})$, but the boundary between the $C$. costata and $S$. wolffii Zones could not be determined. The last occurrence of $T$. annosa places the base of the $S$. delmontensis Zone between Samples 150-904A-32X-4, 60-62 cm (294.21 mbsf), and 150904A-32X-6, 60-62 cm (297.20 mbsf). As at the other sites examined, a number of events co-occur around the Oligocene/Miocene boundary indicating a hiatus between Samples 150-33X-4, 60-62 cm (300.90 mbsf), and 150-904A-33X-6, 60-62 cm (303.90 mbsf). Although this hiatus is not discernible using $\mathrm{Sr}$ isotopes, it is marked by the possible absence of Zone NN1 and a very thin Zone N4. Material below this level belongs to the L. elongata Zone.

\section{COMPARISON OF RADIOLARIAN EVENTS}

Table 4 compares the order in which radiolarian events (morphotypic first and last occurrences) occur at the three sites. Hole 904A was taken as the standard against which the other two sites were compared, and events were then adjusted to minimize the number of outof-sequence events. The sequencing is remarkably consistent considering the nature of the material. Only the first occurrences of Lithopera neotera and Cyrtocapsella japonica in Hole 902D and Hole $904 \mathrm{~A}$, respectively, are seriously out of order. L. neotera is very rare in all sites, and so it is not surprising that its lower limit in Hole 902D is not precise. $C$. japonica, on the other hand, is more abundant, and one would expect to find it at lower levels in Hole 904A. Other outof-sequence events are only off by one sample (approximately $3 \mathrm{~m}$ ), which is not considered to be significant. The occurrence of several events between the same pair of samples suggests a hiatus, but may also reflect sample spacing and/or faunal preservation.

The order of events is, for the most part, consistent with the order found in more tropical sediments (Nigrini, 1985). Minor discrepancies can be attributed to the preservation state of the New Jersey Margin material. For instance, identification of Calocycletta virginis depends upon observation of a complete specimen showing its terminal 
Table 4. Comparison of radiolarian events in Holes 902D, 903C/D, and 904A.

\begin{tabular}{|c|c|c|c|c|c|c|c|}
\hline \multirow{2}{*}{\multicolumn{2}{|c|}{$\begin{array}{c}\text { EPOCH/ZONE } \\
\text { (Riedel \& } \\
\text { Sanfilippo, } \\
1971,1978 \text { ) }\end{array}$}} & \multirow{3}{*}{$\begin{array}{c}\text { RADIOLARIAN } \\
\text { EVENT } \\
\begin{array}{c}\text { B Didymocyrtis } \\
\text { antepenultima }\end{array} \\
\end{array}$} & \multirow{3}{*}{$\begin{array}{l}902 \mathrm{D} \\
\text { (mbsf) } \\
242.00 \\
251.70\end{array}$} & \multirow{3}{*}{$\begin{array}{l}903 \mathrm{C} / \mathrm{D} \\
\text { (mbsf) }\end{array}$} & \multirow{3}{*}{$\begin{array}{l}\text { 904A } \\
\text { (mbsf) }\end{array}$} & \multicolumn{2}{|c|}{ AGE (Ma) (Hodell \& Woodruff, 1994) } \\
\hline & & & & & & $\begin{array}{c}\text { Cande \& Kent, } \\
1992\end{array}$ & $\begin{array}{l}\text { Berggren et } \\
\text { al., } 1985\end{array}$ \\
\hline \multirow{10}{*}{ 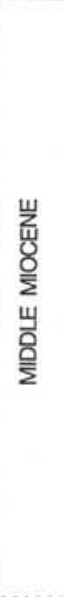 } & \multirow{4}{*}{ 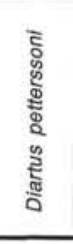 } & & & & & & \\
\hline & & $\begin{array}{c}\text { T Cyrtocapsella } \\
\text { tetrapera }\end{array}$ & $\begin{array}{l}367.20 \\
376.90 \\
\end{array}$ & $\begin{array}{l}749.24 \\
759.80 \\
\end{array}$ & $\begin{array}{l}176.10 \\
179.60 \\
\end{array}$ & 11.79 & 11.48 \\
\hline & & $\begin{array}{l}\text { T Cyrtocapsella } \\
\text { cornuta }\end{array}$ & $\begin{array}{l}443.60 \\
452.90 \\
\end{array}$ & $\begin{array}{l}749.24 \\
759.80 \\
\end{array}$ & $\begin{array}{l}201.60 \\
205.10 \\
\end{array}$ & 11.31 & 10.91 \\
\hline & & $\begin{array}{l}\text { B Dlartus } \\
\text { petterssoni }\end{array}$ & $\begin{array}{l}452.90 \\
462.51 \\
\end{array}$ & $\begin{array}{l}807.38 \\
815.91 \\
\end{array}$ & $\begin{array}{l}230.10 \\
233.40 \\
\end{array}$ & & \\
\hline & \multirow{11}{*}{ 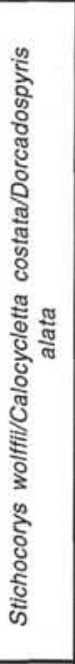 } & $\begin{array}{l}\mathrm{T} \text { Didymocyrtis } \\
\text { mammifera }\end{array}$ & $\begin{array}{l}462.51 \\
472.19 \\
\end{array}$ & & $\begin{array}{l}230.10 \\
233.40 \\
\end{array}$ & & \\
\hline & & $\begin{array}{l}\text { B Lithopera } \\
\text { neotera }\end{array}$ & $\begin{array}{l}386.50 \\
396.20 \\
\end{array}$ & & $\begin{array}{l}236.40 \\
239.40 \\
\end{array}$ & 14.46 & 14.50 \\
\hline & & $\begin{array}{l}\text { B Phormostichoartus } \\
\text { corbula }\end{array}$ & $\begin{array}{l}452.90 \\
462.51 \\
\end{array}$ & $\begin{array}{l}815.91 \\
826.71 \\
\end{array}$ & $\begin{array}{l}236.40 \\
239.40 \\
\end{array}$ & & \\
\hline & & $\begin{array}{l}\text { T Calocycletta } \\
\text { virginis }\end{array}$ & $\begin{array}{l}491.48 \\
501.20 \\
\end{array}$ & $\begin{array}{l}855.61 \\
865.30 \\
\end{array}$ & $\begin{array}{l}239.40 \\
243.00 \\
\end{array}$ & & \\
\hline & & $\begin{array}{l}\text { B Didymocyrtis } \\
\text { laticonus }\end{array}$ & $\begin{array}{l}462.51 \\
472.19 \\
\end{array}$ & $\begin{array}{l}865.30 \\
874.90 \\
\end{array}$ & $\begin{array}{l}249.00 \\
252.40 \\
\end{array}$ & $13.78^{*}$ & $13.80^{*}$ \\
\hline & & $\begin{array}{l}\text { T Didymocyrtis } \\
\text { tubaria }\end{array}$ & $\begin{array}{l}501.20 \\
510.80 \\
\end{array}$ & $\begin{array}{l}865.30 \\
874.90 \\
\end{array}$ & $\begin{array}{l}252.40 \\
255.40 \\
\end{array}$ & & \\
\hline \multirow{19}{*}{ 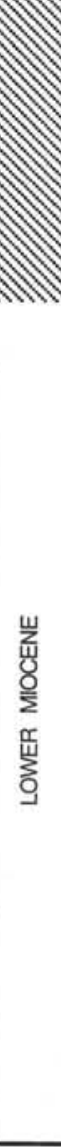 } & & $\begin{array}{l}\text { T Didymocyrtis } \\
\text { violina }\end{array}$ & $\begin{array}{l}520.59 \\
530.30 \\
\end{array}$ & $\begin{array}{l}903.80 \\
913.30\end{array}$ & $\begin{array}{l}255.40 \\
257.90 \\
\end{array}$ & & \\
\hline & & $\begin{array}{l}\text { B Didymocyrtis } \\
\text { mammifera }\end{array}$ & $\begin{array}{l}520.59 \\
530.30 \\
\end{array}$ & $\begin{array}{l}932.35 \\
942.15 \\
\end{array}$ & $\begin{array}{l}255.40 \\
257.90 \\
\end{array}$ & & \\
\hline & & $\begin{array}{l}\text { T Eucyrtidium } \\
\text { diaphanes }\end{array}$ & $\begin{array}{l}549.10 \\
558.60 \\
\end{array}$ & $\begin{array}{l}903.80 \\
913.30\end{array}$ & $\begin{array}{l}255.40 \\
257.90 \\
\end{array}$ & & \\
\hline & & $\begin{array}{l}\text { T Spongasteriscus } \\
\text { marylandicus }\end{array}$ & $\begin{array}{l}549.10 \\
558.60\end{array}$ & $\begin{array}{l}942.15 \\
952.18\end{array}$ & $\begin{array}{l}268.20 \\
271.90 \\
\end{array}$ & & \\
\hline & & $\begin{array}{l}\text { B Stichocorys } \\
\text { wolffii }\end{array}$ & $\begin{array}{l}558.60 \\
568.21 \\
\end{array}$ & $\begin{array}{l}952.18 \\
961.80 \\
\end{array}$ & $\begin{array}{l}284.60 \\
287.60 \\
\end{array}$ & & \\
\hline & \multirow{10}{*}{ 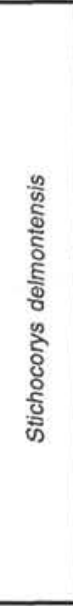 } & $\begin{array}{l}\text { B Didymocyrtis } \\
\text { violina }\end{array}$ & $\begin{array}{l}568.21 \\
577.98 \\
\end{array}$ & $\begin{array}{l}952.18 \\
961.80 \\
\end{array}$ & $\begin{array}{l}284.60 \\
287.60 \\
\end{array}$ & & \\
\hline & & $\begin{array}{l}\text { T Calocycletta } \\
\text { serrata }\end{array}$ & & & $\begin{array}{l}284.60 \\
287.60 \\
\end{array}$ & & \\
\hline & & $\begin{array}{l}\text { B Stichocorys } \\
\text { delmontensis }\end{array}$ & $\begin{array}{l}568.21 \\
577.98 \\
\end{array}$ & $\begin{array}{l}952.18 \\
961.80 \\
\end{array}$ & $\begin{array}{l}287.60 \\
291.20 \\
\end{array}$ & 21.77 & 21.89 \\
\hline & & $\begin{array}{l}\text { B Didymocyrtis } \\
\text { tubaria }\end{array}$ & $\begin{array}{l}577.98 \\
587.61 \\
\end{array}$ & $\begin{array}{l}952.18 \\
961.80 \\
\end{array}$ & $\begin{array}{l}291.20 \\
294.21 \\
\end{array}$ & & \\
\hline & & $\begin{array}{l}\text { T Calocycletta } \\
\text { robusta }\end{array}$ & $\begin{array}{l}577.98 \\
587.61 \\
\end{array}$ & $\begin{array}{l}942.15 \\
952.18 \\
\end{array}$ & $\begin{array}{l}291.20 \\
294.21 \\
\end{array}$ & & \\
\hline & & $\begin{array}{l}\text { B Calocycletta } \\
\text { virginis }\end{array}$ & $\begin{array}{l}577.98 \\
587.61 \\
\end{array}$ & $\begin{array}{l}952.18 \\
961.80 \\
\end{array}$ & $\begin{array}{l}294.21 \\
297.20 \\
\end{array}$ & $23.62^{* *}$ & $23.50^{* *}$ \\
\hline & & $\begin{array}{l}\text { B Cyrtocapsella } \\
\text { Japonica }\end{array}$ & $\begin{array}{l}587.61 \\
595.80 \\
\end{array}$ & & $\begin{array}{l}284.60 \\
287.60 \\
\end{array}$ & & \\
\hline & & $\begin{array}{l}\text { T Didymocyrtis } \\
\text { prismatica }\end{array}$ & $\begin{array}{l}587.60 \\
595.80 \\
\end{array}$ & & $\begin{array}{l}294.21 \\
297.20 \\
\end{array}$ & 16.44 & 16.65 \\
\hline & & $\begin{array}{l}\text { T Lychnocanoma } \\
\text { elongata }\end{array}$ & $\begin{array}{l}595.80 \\
606.88 \\
\end{array}$ & & $\begin{array}{l}294.21 \\
297.20 \\
\end{array}$ & 16.67 & 16.90 \\
\hline & & $\begin{array}{l}\text { T Theocyrtis } \\
\text { annosa }\end{array}$ & $\begin{array}{l}595.80 \\
606.88 \\
\end{array}$ & & $\begin{array}{l}294.21 \\
297.20 \\
\end{array}$ & $22.42^{* *}$ & $22.93^{* *}$ \\
\hline & \multirow{4}{*}{ 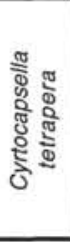 } & $\begin{array}{l}\text { T Eucyrtidium } \\
\text { sp. }\end{array}$ & $\begin{array}{l}606.88 \\
616.63 \\
\end{array}$ & $\begin{array}{c}998.56 \\
1009.80 \\
\end{array}$ & $\begin{array}{l}300.90 \\
303.90 \\
\end{array}$ & & \\
\hline & & $\begin{array}{l}\text { B Cyrtocapsella } \\
\text { cornuta }\end{array}$ & $\begin{array}{l}606.88 \\
616.63 \\
\end{array}$ & $\begin{array}{c}998.56 \\
1009.80 \\
\end{array}$ & $\begin{array}{l}303.90 \\
306.90 \\
\end{array}$ & 23.63 & 23.51 \\
\hline & & $\begin{array}{l}\text { B Calocycletta } \\
\text { serrata }\end{array}$ & & & $\begin{array}{l}303.90 \\
306.90 \\
\end{array}$ & & \\
\hline & & $\begin{array}{l}\text { B Cyrtocapsella } \\
\text { tetrapera }\end{array}$ & $\begin{array}{l}606.88 \\
616.63 \\
\end{array}$ & $\begin{array}{c}998.56 \\
1009.80 \\
\end{array}$ & $\begin{array}{l}303.90 \\
306.90 \\
\end{array}$ & $23.62^{* *}$ & $23.50^{* *}$ \\
\hline \multirow{4}{*}{$\begin{array}{l}\text { 岁 } \\
\text { 夏 } \\
\text { 옳 }\end{array}$} & \multirow{4}{*}{ 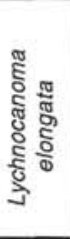 } & $\begin{array}{l}\text { T Artophormis } \\
\text { gracilis }\end{array}$ & $\begin{array}{l}606.88 \\
616.63 \\
\end{array}$ & $\begin{array}{c}998.56 \\
1009.80 \\
\end{array}$ & $\begin{array}{l}303.90 \\
306.90 \\
\end{array}$ & 23.94 & 23.97 \\
\hline & & $\begin{array}{l}\text { B Lychnocanoma } \\
\text { elongata }\end{array}$ & $\begin{array}{l}616.63 \\
625.80 \\
\end{array}$ & & $\begin{array}{l}313.50 \\
316.50 \\
\end{array}$ & 24.60 & 25.24 \\
\hline & & $\begin{array}{l}\text { B Eucyrtidium } \\
\text { diaphanes }\end{array}$ & $\begin{array}{c}\text { below } \\
674.09 \\
\end{array}$ & $\begin{array}{l}1037.37 \\
1056.71 \\
\end{array}$ & $\begin{array}{l}325.90 \\
329.30 \\
\end{array}$ & 23.94 & 23.97 \\
\hline & & $\begin{array}{l}\text { B Cyrtocapsella } \\
\text { robusta }\end{array}$ & $\begin{array}{l}625.8 \\
635.5 \\
\end{array}$ & $\begin{array}{l}1009.80 \\
1028.52 \\
\end{array}$ & $\begin{array}{l}329.30 \\
332.30 \\
\end{array}$ & & \\
\hline
\end{tabular}

Notes: $\mathrm{T}=$ last morphotypic occurrence; $\mathrm{B}=$ first morphotypic occurrence. Shaded boxes indicate out-of-sequence events. ${ }^{*}=$ age from Johnson and Nigrini $(1985)$; $*=$ age modified by Sanfilippo and Nigrini (1995, in press). 
Table 5. Calculated maximum age range of radiolarian events in Hole 902D.

\begin{tabular}{|c|c|c|c|c|c|c|c|c|c|c|c|c|c|c|}
\hline \multirow{3}{*}{\multicolumn{2}{|c|}{$\begin{array}{l}\text { RADIOLARIAN } \\
\text { EVENT }\end{array}$}} & \multicolumn{2}{|c|}{ RANGE OF TAXON } & \multicolumn{7}{|c|}{ STRONTIUM ISOTOPES } & \multicolumn{4}{|c|}{ RADIOLARIAN EVENT AGE } \\
\hline & & \multirow{2}{*}{\begin{tabular}{|c|} 
UPPERUMIT \\
(mbsf) \\
\end{tabular}} & \multirow{2}{*}{$\begin{array}{c}\text { LOWERLIMIT } \\
\text { (mbst) }\end{array}$} & \multicolumn{2}{|c|}{ AGE ABOVE (Ma) } & \multicolumn{2}{|c|}{ AGE BEL OW (Ma) } & \multirow{2}{*}{$\begin{array}{c}\text { DEPTHABOVE } \\
\text { (mbsf) }\end{array}$} & \multirow{2}{*}{\begin{tabular}{|c|} 
DEPTHBEIOW \\
(mbsf)
\end{tabular}} & \multirow{2}{*}{$\begin{array}{c}\text { EAOR } \\
(+ \text { or }-\mathrm{Ma})\end{array}$} & \multicolumn{2}{|c|}{ MIN (Ma) } & \multicolumn{2}{|c|}{ MAX (Ma) } \\
\hline & & & & BKFV85 & CK92 & BKFV85 & СK92 & & & & BKFV85 & CK92 & BKFV85 & CK92 \\
\hline$T$ & Lvchnocanoma elongata & 595.80 & 606.88 & 22.04 & 22.78 & 22.96 & 23.41 & 595.52 & 603.77 & 1.00 & \begin{tabular}{|l|}
21.07 \\
\end{tabular} & 21.80 & 24.31 & 24.65 \\
\hline$T$ & Theocyrtis annosa & 595.80 & 606.88 & 22.04 & 22.78 & 22.96 & 23.41 & 595.52 & 603.77 & 1.00 & 21.07 & 21.80 & 24.31 & 24.65 \\
\hline$T$ & Eucyrtidium so. & 606.88 & 616.63 & 23.16 & 23.54 & 26.61 & 25.88 & 609.80 & 616.46 & 1.00 & \begin{tabular}{|l|}
20.65 \\
\end{tabular} & 21.51 & 27.70 & 26.94 \\
\hline B & Cyrtocapsella cornuta & 606.88 & 616.63 & 23.16 & 23.54 & 26.61 & 25.88 & 609.80 & 616.46 & 1.00 & 20.65 & 21.51 & 27.70 & 26.94 \\
\hline$B$ & Calocycle & & & & & & & & & & & & & \\
\hline & & & & & & & & & & & & & & \\
\hline B & Cyrtocapsella tetrapera & 606.88 & 616.63 & 23.16 & 23.54 & 26.61 & 25.88 & 609.80 & 616.46 & 1.00 & 20.65 & 21.51 & 27.70 & 26.94 \\
\hline$T$ & Artophormis gracilis & 606.88 & 616.63 & 23.16 & 23.54 & 26.61 & 25.88 & 609.80 & 616.46 & 1.00 & 20.65 & 21.51 & 27.70 & 26.94 \\
\hline B & Lychnocanoma elongata & 616.63 & 625.80 & 26.61 & 25.88 & 25.50 & 25.80 & 616.46 & 625.70 & 1.00 & 25.61 & 24.88 & 27.50 & 26.80 \\
\hline B & Cyrtocapsella robusta & 625.80 & 635.50 & 27.07 & 26.19 & 27.94 & 26.77 & 628.73 & 635.41 & 1.00 & 25.69 & 24.94 & 28.95 & 27.78 \\
\hline B & Eucyrtidium diaphanes & & & & & & & & & & & & & \\
\hline & & & & & & & & & & & & & & \\
\hline
\end{tabular}

Notes: Ages based on the stratigraphic upper and lower limit of the event and an age derived from strontium isotope analyses (Miller et al., this volume) above and below that range. BKFV85 = ages calculated using the GPTS of Berggren et al. (1985); CK92 = ages calculated using the GPTS of Cande and Kent (1992). T = last morphotypic occurrence; B = first morphotypic occurrence.

feet. Specimens in the material described herein are often incomplete. There are, however, three major discrepancies. In tropical sediments, the first occurrence of $C$. japonica is within the middle Miocene $D$. petterssoni Zone, whereas on the New Jersey Margin its first occurrence is much older in the lower Miocene $S$. delmontensis Zone. The last occurrences of Didymocyrtis prismatica and of $L$. elongata in tropical sediments are within the upper lower Miocene $C$. costata Zone, whereas on the New Jersey Margin they are somewhat older, in the $S$. delmontensis Zone. Because other events around this time are not out of order, these discrepancies cannot be attributed to disruptions in sedimentation, but represent truly diachronous events.

\section{ABSOLUTE AGE OF RADIOLARIAN EVENTS}

By combining the radiolarian biostratigraphic determinations and absolute ages derived from strontium isotope analyses at the three sites, it has been possible to compare the ages obtained at these sites with those previously established in other sectors of the world oceans. The stated error bars for a single analysis (Miller et al., this volume) for the Sr-derived ages are: $\pm 1.0 \mathrm{~m}$.y. for $\sim 38$ to $22.8 \mathrm{Ma}$; $\pm 0.6 \mathrm{~m} . \mathrm{y}$. for 22.8 to $15.6 \mathrm{Ma}$; and $\pm 1.4 \mathrm{~m}$.y. for 15.2 to $\sim 10 \mathrm{Ma}$. This is the worst-case scenario; Miller and his co-workers have indicated that their geological results suggest that smaller error bars may apply. The data is presented using the time scale of Berggren et al. (1985) and of Cande and Kent (1992). Tables 5-7 show the calculated age range for the radiolarian events recognized in this study. In some cases, where no age data is available, it has been possible to bracket the event between events of a known age. In Figures 2 and 3, age ranges have been plotted for each site along with ages derived from other studies, principally those of Hodell and Woodruff (1994) and Sanfilippo and Nigrini (1995; in press). The ages from Hodell and Woodruff (1994) are based on strontium isotope derived ages for DSDP Site 289 in the western tropical Pacific. Some of these ages were subsequently modified by Sanfilippo and Nigrini (1995; in press) after further examination of the radiolarian fauna at Site 289.

\section{Oligocene to Lowermost Miocene}

Strontium isotope data are available from all three sites in the Oligocene to lowermost Miocene part of the section, and it is in this interval that the radiolarian fauna is best preserved. Also, in this inter- val, we have the greatest confidence in the $\mathrm{Sr}$ isotope ages reported by Hodell and Woodruff (1994), because the radiolarian events at Site 289 were re-examined by Sanfilippo and Nigrini (1995; in press) in the light of present-day species concepts and those concepts are applied herein. Consequently, the last occurrences of $A$. gracilis and $T$. annosa (two sites only) and the first occurrences of $L$. elongata (two sites only), C. cornuta, and C. tetrapera (Figs. 2,3) all have overlapping ranges and are consistent with the ages reported by Hodell and Woodruff (1994). In the same interval, the first occurrence of Calocycletta robusta and the last occurrence of Eucyrtidium sp. are internally consistent, although there are no $\mathrm{Sr}$ isotope age data available for these events. For the first occurrences of Calocycletta serrata and $E$. diaphanes strontium isotope data are available only from Hole 904A. There are no $\mathrm{Sr}$ isotope data for the $C$. serrata event and the externally derived age for $E$. diaphanes is younger than that calculated in Hole 904A. The radiolarian data from Sites 902 and 903 suggest that the first occurrence of $E$. diaphanes may be even older than that calculated for Hole 904A. Hence, it may be that the first occurrence of $E$. diaphanes is a diachronous event.

\section{Lower Miocene}

In this interval, there are strontium isotope determinations only for Sites 903 and 904 . The calculated age range (21.19 to 23.32 m.y.) for the last occurrence of $L$. elongata overlap, but are vastly different from the 16.44 m.y. reported by Hodell and Woodruff (1994). In fact, the species is extremely rare in the New Jersey Margin material and it is known to prefer warmer waters. Hence, its disappearance far below the level of its tropical disappearance could be construed as a slight cooling of the sea water at about $22 \mathrm{Ma}$. A similar discrepancy can be noted in regard to the last occurrence of $D$. prismatica.

The next four events (first occurrences of $C$. virginis, Didymocyrtis tubaria, and $S$. delmontensis and last occurrence of $C$. robusta) do not have overlapping ranges, but the Site 904 ranges coincide with the Hodell and Woodruff (1994) age data for the first occurrences of C. virginis and $S$. delmontensis. The presence of a hiatus associated with seismic Reflector m5.4 at Site 903 may have produced erroneous radiolarian data with respect to the first occurrences, but does not explain the discrepancy associated with the last occurrence.

Only Site 904 strontium isotope data are available for the first occurrence of $C$. japonica and the last occurrence of $C$. serrata. Although there are no $\mathrm{Sr}$ isotope age determinations for the last occur- 
Table 6. Calculated maximum age range of radiolarian events in Holes $903 \mathrm{C} / \mathrm{D}$.

\begin{tabular}{|c|c|c|c|c|c|c|c|c|c|c|c|c|c|c|}
\hline \multirow{3}{*}{\multicolumn{2}{|c|}{ RADIOLARIANEVENT }} & \multicolumn{2}{|c|}{ RANGE OF TAXON } & \multicolumn{7}{|c|}{ STRONTIUM ISOTOPES } & \multicolumn{4}{|c|}{ RADIOLARIAN EVENT AGE } \\
\hline & & \multirow{2}{*}{$\begin{array}{c}\text { UPPERUMT } \\
\text { (mbsf) }\end{array}$} & \multirow{2}{*}{$\begin{array}{l}\text { LOWERLIMT } \\
\text { (mbsf) }\end{array}$} & \multicolumn{2}{|c|}{ AGE ABOVE (Ma) } & \multicolumn{2}{|c|}{ AGE BELOW (Ma) } & \multirow{2}{*}{$\begin{array}{c}\text { DEPTH ABOVE } \\
\text { (mbsf) }\end{array}$} & \multirow{2}{*}{$\begin{array}{c}\text { DEPTHBELOW } \\
\text { (mbsf) }\end{array}$} & \multirow{2}{*}{$\begin{array}{c}\text { PRAOA } \\
\text { (+ or - Ma) }\end{array}$} & \multicolumn{2}{|c|}{ MIN (Ma) } & \multicolumn{2}{|c|}{$\operatorname{MAX}(\mathrm{Ma})$} \\
\hline & & & & BKFV85 & CK92 & BKFV85 & CK92 & & & & BKFV85 & СК92 & BKFV85 & CK92 \\
\hline \multicolumn{15}{|c|}{ T Cyrtocapsella tetrapera } \\
\hline \multirow{2}{*}{\multicolumn{15}{|c|}{ T Cyrtocapsella cornuta }} \\
\hline & & & & & & & & & & & & & & \\
\hline B & Diartus petterssoni & 807.38 & 815.91 & 12.47 & 12.67 & 12.56 & 12.75 & 807.30 & 829.62 & 1.40 & 11.07 & 11.27 & 13.90 & 14.10 \\
\hline$T$ & \multicolumn{14}{|l|}{ T Didymocyrtis mammifora } \\
\hline \multirow{2}{*}{\multicolumn{15}{|c|}{ B Lithopera neotera }} \\
\hline & & & & & & & & & & & & & & \\
\hline B & Phormostichoartus corbula & 815.91 & 826.71 & 12.47 & 12.67 & 12.56 & 12.75 & 807.30 & 829.62 & 1.40 & 11.10 & 11.30 & 13.95 & 14.14 \\
\hline & & & & & & & & & & & & & & \\
\hline$T$ & Calocycletta virginis & 855.61 & 865.30 & 15.70 & 15.38 & 15.25 & 15.00 & 852.49 & 874.78 & 0.60 & 15.04 & 14.73 & 16.04 & 15.76 \\
\hline$B$ & Didymocyrtis laticonus & 865.30 & 874.90 & 15.70 & 15.38 & 15.25 & 15.00 & 852.49 & 874.78 & 0.60 & 14.84 & 14.56 & 15.85 & 15.60 \\
\hline$T$ & Didymocyrtis tubaria & 865.30 & 874.90 & 15,70 & 15.38 & 15.25 & 1500 & 85249 & 874.78 & 0.60 & 14.84 & 14.56 & 1585 & 1560 \\
\hline & & & & & & & & & & & & & 10.00 & 10.00 \\
\hline$B$ & Didymocyrtis mammifera & 932.35 & 942.15 & 18.22 & 17.95 & 18.28 & 18.01 & 929.36 & 942.05 & 0.60 & 17.63 & 17.36 & 18.88 & 18.61 \\
\hline$T$ & Eucyrtidium diaphanes & 903.80 & 913.30 & 16.32 & 16.01 & 18.17 & 17.89 & 903.71 & 910.20 & 0.60 & 15.75 & 15.44 & 19.65 & 19.39 \\
\hline & & & & & & & & & & & & & & \\
\hline$T$ & Spongasteriscus marylandicus & 942.15 & 952.18 & 18.28 & 18.01 & 18.37 & 18.09 & 942.05 & 949.70 & 0.60 & 17.68 & 17.41 & 19.00 & 18.72 \\
\hline B & Stichocorys wolffii & 952.18 & 961.80 & 18.37 & 18.09 & 20.57 & 20.32 & 949.70 & 971.11 & 0.60 & 18.02 & 17.75 & 20.21 & 19.95 \\
\hline$B$ & Didymocyrtis violina & 952.18 & 961.80 & 18.37 & 18.09 & 20.57 & 20.32 & 949.70 & 971.11 & 0.60 & 18.02 & 17.75 & 20.21 & 19.95 \\
\hline & & & & & & & & & & & & & & \\
\hline \multicolumn{15}{|c|}{ T Calocycletta serrata } \\
\hline$B$ & Cyrtocapsella japonica & & & & & & & & & & & & & \\
\hline & & & & & & & & & & & & & & \\
\hline B. & Stichocorys delmontensis & 952.18 & 961.80 & 18.37 & 18.09 & 20.57 & 20.32 & 949.70 & 971.11 & 0.60 & 18.02 & 17.75 & 20.21 & 19.95 \\
\hline B & Didymocyrtis tubaria & 952.18 & 961.80 & 18.37 & 18.09 & 20.57 & 20.32 & 949.70 & 971.11 & 0.60 & 18.02 & 17.75 & 20.21 & 19.95 \\
\hline & & & & & & & & & & & & & & \\
\hline $\begin{array}{llllllll}T & \end{array}$ & Calocycletta robusta & 942.15 & 952.18 & 18.22 & 17.95 & 20.57 & 20.32 & 929.36 & 971.11 & 0.60 & 18.34 & 18.08 & 20.10 & 19.85 \\
\hline B & Calocycletta virginis & 952.18 & 961.80 & 18.09 & 18.09 & 20.57 & 20.32 & 949.70 & 971.11 & 0.60 & 17.78 & 17.75 & 20.09 & 19.95 \\
\hline$T$ & Didymocyrtis prismatica & & & & & & & & & & & & & \\
\hline & & & & & & & & & & & & & & \\
\hline$T$ & Lychnocanoma elongata & & & & & & & & & & & & & \\
\hline$T$ & Theocyrtis annosa & & & & & & & & & & & & & \\
\hline & & & & & & & & & & & & & & \\
\hline$T$ & Eucyrtidium so. & 998.56 & 1009.80 & 24.03 & 24.13 & 27.82 & 26.69 & 1003.03 & 1007.30 & 1.00 & 19.06 & 20.45 & 31.04 & 29.19 \\
\hline 8 & Cyrtocapsella cornuta & 998.56 & 1009.80 & 24.03 & 24.13 & 27.82 & 26.69 & 1003.03 & 1007.30 & 1.00 & 19.06 & 20.45 & 31.04 & 29.19 \\
\hline B & Calocycletta serrata & & & & & & & & & & & & & \\
\hline & & & & & & & & & & & & & & \\
\hline$B$ & Cyrtocapsella tetrapera & 998.56 & 1009.80 & 24.03 & 24.13 & 27.82 & 26.69 & 1003.03 & 1007.30 & 1.00 & 19.06 & 20.45 & 31.04 & 29.19 \\
\hline$T$ & Artophormis gracilis & 998.56 & 1009.80 & 24.03 & 24.13 & 27.82 & 26.69 & 1003.03 & 1007.30 & 1.00 & 19.06 & 20.45 & 31.04 & 29.19 \\
\hline & & & & & & & & & & & & & & \\
\hline B & Lychnocanoma elongata & & & & & & & & & & & & & \\
\hline$B$ & Cyrtocapsella robusta & 1009.80 & 1028.52 & 27.82 & 26.69 & 28.20 & 26.95 & 1007.30 & 1028.17 & 1.00 & 26.87 & 25.72 & 29.21 & 27.95 \\
\hline A & & & & & & & & & & & & & & \\
\hline 8 & Eucyrtidium diaphanes & & & & & & & & & & & & & \\
\hline
\end{tabular}

Notes: See Table 5.

rence of $C$. serrata, its stratigraphic position is consistent with other qualitative data. However, the first appearance of $C$. japonica is usually much younger, at the base of the $D$. petterssoni Zone, and it is probable that this is a diachronous event.

In the remainder of the lower Miocene, the calculated ages for the first occurrences of $D$. violina, $S$. wolffii, and D. mammifera and the last occurrences of Spongastericus marylandicus and E. diaphanes are consistent (or nearly so) between the two sites.

\section{Middle Miocene}

The ages calculated for the middle Miocene radiolarian events are either internally consistent between Sites 904 and 903 or have only a single age determination. The ages reported by Hodell and Woodruff (1994) for the first occurrences of L. neotera and D. petterssoni and the last occurrences of $C$. cornuta and $C$. tetrapera are consistent with the Leg 150 data. The Hodell and Woodruff (1994) age for the 
Table 7. Calculated maximum age range of radiolarian events in Hole 904A.

\begin{tabular}{|c|c|c|c|c|c|c|c|c|c|c|c|c|c|c|}
\hline & \multirow{3}{*}{ RADIOLARIAN EVENT } & \multicolumn{2}{|c|}{ RANGE OF TAXON } & \multicolumn{7}{|c|}{ STRONTIUMISOTOPES } & \multicolumn{4}{|c|}{ RADIOLARIAN EVENT AGE } \\
\hline & & \multirow{2}{*}{$\begin{array}{l}\text { UPPERLIMT } \\
\text { (mbsf) }\end{array}$} & \multirow{2}{*}{$\begin{array}{l}\text { LOWERLIMIT } \\
\text { (mbst) }\end{array}$} & \multicolumn{2}{|c|}{ AGE ABOVE (Ma) } & \multicolumn{2}{|c|}{ AGE BELOW (Ma) } & \multirow{2}{*}{$\begin{array}{c}\text { DEPTHABOVE } \\
\text { (mbsf) }\end{array}$} & \multirow{2}{*}{$\begin{array}{c}\text { DEPTHBELOW } \\
\text { (mbsf) }\end{array}$} & \multirow{2}{*}{$\begin{array}{c}\text { FAOR } \\
\text { (+ or - Ma) }\end{array}$} & \multicolumn{2}{|c|}{ MIN (Ma) } & \multicolumn{2}{|c|}{$\operatorname{MAX}$ (Ma) } \\
\hline & & & & BKFV85 & CK29 & BKFV85 & CK29 & & & & BKFV85 & CK29 & BKFV85 & CK29 \\
\hline$T$ & Cyrtocapsella tetrapera & 176.10 & 179.60 & 12.92 & 13.05 & 11.57 & 11.92 & 172.10 & 188.10 & 1.40 & 11.18 & 11.37 & 13.69 & 13.92 \\
\hline$T$ & Cyrtocapsella cornuta & 201.60 & 205.10 & 12.51 & 12.71 & 12.11 & 12.27 & 197.60 & 204.10 & 1.40 & 10.86 & 11.04 & 13.45 & 13.60 \\
\hline 8 & Diartus petterssoni & 230.10 & 233.40 & 13.46 & 13.50 & 12.96 & 13.09 & 213.60 & 232.40 & 1.40 & 11.62 & 11.74 & 14.33 & 14.47 \\
\hline$T$ & Didymocyntis mammitera & 230.10 & 233.40 & 13.46 & 13.50 & 12.96 & 13.09 & 213.60 & 232.40 & 1.40 & 11.62 & 11.74 & 14.33 & 14.47 \\
\hline 8 & Lithopera neotera & 236.40 & 239.40 & 12.96 & 13.09 & 12.96 & 13.09 & 232.40 & 238.40 . & 1.40 & 11.56 & 11.69 & 14.36 & 14.49 \\
\hline 8 & Phormostichoartus corbula & 236.40 & 239.40 & 12.96 & 13.09 & 12.96 & 13.09 & 232.40 & 238.40 & 1.40 & 11.56 & 11.69 & 14.36 & 14.49 \\
\hline$T$ & Calocycletta virginis & 239.40 & 243.00 & 12.96 & 13.09 & 15.96 & 15.65 & 238.40 & 245.00 & 1.40 & 12.01 & 12.08 & 16.45 & 16.27 \\
\hline$B$ & & & & & & & & & & & & & & \\
\hline & Didymocyntis laticonus & 249.00 & 252.40 & 15.96 & 15.65 & 16.29 & 15.99 & 245.00 & 251.40 & 0.60 & 15.57 & 15.26 & 16.94 & 16.64 \\
\hline T & Didymocyntis tubaria & 252.40 & 255.40 & 16.29 & 15.99 & 16.85 & 16.56 & 251.40 & 257.39 & 0.60 & 15.78 & 15.49 & 17.26 & 16.97 \\
\hline 8 & Didyrnocyntis mammifera & 255.40 & 257.90 & 16.29 & 15.99 & 16.85 & 16.56 & 251.40 & 257.39 & 0.60 & 16.06 & 15.77 & 17.50 & 17.21 \\
\hline$T$ & Eucyntidium diaphanes & 255.40 & 257.90 & 16.29 & 15.99 & 16.85 & 16.56 & 251.40 & 257.39 & 0.60 & 16.06 & 15.77 & 17.50 & 17.21 \\
\hline$T$ & & & & & & & & & & & & & & \\
\hline r & Spongasteriscus marylandicus & 268.20 & 271.90 & 18.12 & 17.84 & 18.74 & 18.47 & 264.20 & 270.90 & 0.60 & 17.89 & 17.62 & 19.43 & 19.16 \\
\hline B & Stichocorys wolffii & 284.60 & 287.60 & 20.00 & 19.75 & 21.55 & 21.31 & 283.60 & 288.10 & 0.60 & 19.74 & 19.50 & 21.98 & 21.74 \\
\hline 8 & Didymocyntis violina & 284.60 & 287.60 & 20.00 & 19.75 & 21.55 & 21.31 & 283.60 & 288.10 & 0.60 & 19.74 & 19.50 & 21.98 & 21.74 \\
\hline T & Calocycletta serrata & 284.60 & 287.60 & 20.00 & 19.75 & 21.55 & 21.31 & 283.60 & 288.10 & 0.60 & 19.74 & 19.50 & 21.98 & 21.74 \\
\hline 8 & Cyrtocapsellia japonica & 284.60 & 287.60 & 20.00 & 19.75 & 21.55 & 21.31 & 283.60 & 288.10 & 0.60 & 19.74 & 19.50 & 21.98 & 21.74 \\
\hline$B$ & Stichocorys delmontensis & 287.60 & 291.20 & 21.55 & 21.31 & 21.48 & 21.24 & 288.10 & 293.20 & 0.60 & 20.96 & 20.72 & 22.11 & 21.87 \\
\hline$B$ & Didymocyntis tubaria & 291.20 & 294.21 & 21.55 & 21.31 & 21.48 & 21.24 & 288.10 & 293.20 & 0.60 & 20.91 & 20.67 & 22.07 & 21.83 \\
\hline$T$ & Calocycletta robusta & 291.20 & 294.21 & 21.55 & 21.31 & 21.48 & 21.24 & 288.10 & 293.20 & 0.60 & 20.91 & 20.67 & 22.07 & 21.83 \\
\hline B & Calocycletta virginis & 294.21 & 297.20 & 21.48 & 21.24 & 22.88 & 22.66 & 293.20 & 297.70 & 0.60 & 21.19 & 20.96 & 23.32 & 23.10 \\
\hline$T$ & Didymocyntis prismatica & 294.21 & 297.20 & 21.48 & 21.24 & 22.88 & 22.66 & 293.20 & 297.70 & 0.60 & 21.19 & 20.96 & 23.32 & 23.10 \\
\hline$T$ & Lychnocanoma elongata & 294.21 & 297.20 & 21.48 & 21.24 & 22.88 & 22.66 & 293.20 & 297.70 & 0.60 & 21.19 & 20.96 & 23.32 & 23.10 \\
\hline$T$ & Theocyntis annosa & 294.21 & 297.20 & 21.48 & 21.24 & 22.88 & 22.66 & 293.20 & 297.70 & 0.60 & 21.19 & 20.96 & \begin{tabular}{|l|}
23.32 \\
\end{tabular} & 23.10 \\
\hline$T$ & Eucyrtidium sD. & 300.90 & 303.90 & 22.56 & 22.34 & 23.02 & 23.44 & 299.90 & 302.90 & 1.00 & 21.71 & 21.71 & 24.17 & 24.81 \\
\hline 8 & & & & & & & & & & & & & & \\
\hline & & 303.90 & 306.90 & 23.02 & 23.44 & 24.05 & 24.14 & 302.90 & 309.50 & 1.00 & 22.18 & 22.55 & 24.64 & 24.86 \\
\hline 8 & Calocycletta serrata & 303.90 & 306.90 & 23.02 & 23.44 & 24.05 & 24.14 & 302.90 & 309.50 & 1.00 & 22.18 & 22.55 & 24.64 & 24.86 \\
\hline$B$ & Cyrtocapsella tetrapera & 303.90 & 306.90 & 23.02 & 23.44 & 24.05 & 24.14 & 302.90 & 309.50 & 1.00 & 22.18 & 22.55 & \begin{tabular}{|l|}
24.64 \\
\end{tabular} & 24.86 \\
\hline$T$ & Artophormis gracilis & 303.90 & 306.90 & 23.02 & 23.44 & 24.05 & 24.14 & 302.90 & 309.50 & 1.00 & 22.18 & 22.55 & 24.64 & 24.86 \\
\hline 8 & Lychnocanoma elongata & 313.50 & 316.50 & 24.66 & 24.55 & 24.80 & 24.65 & 312.50 & 315.50 & 1.00 & 23.17 & 23.58 & 25.85 & 25.68 \\
\hline & & & & & & & & & & & & & & \\
\hline B & Cyrtocapsella robusta & 329.30 & 332.30 & 26.27 & 25.64 & 26.19 & 26.27 & 324.88 & 331.28 & 1.00 & 25.21 & 25.08 & 27.18 & 27.37 \\
\hline$B$ & Eucyntidium diaphanes & 325.90 & 329.30 & 26.27 & 25.64 & 26.19 & 26.27 & 324.88 & 331.28 & 1.00 & 25.26 & 24.74 & 27.21 & 27.08 \\
\hline
\end{tabular}

Notes: See Table 5 .

first occurrence of $D$. laticonus is younger than the age determined herein, but this could well be an identification problem since $D$. laticonus is part of an evolutionary sequence and is not always easy to identify. On the other hand, it could represent a truly diachronous event. The Site 904 age for the last occurrence of $C$. virginis is consistent with that reported by Johnson and Nigrini (1985). There are no external age data for the last occurrences of $D$. tubaria and $D$. mammifera or the first occurrence of Phormostichoartus corbula.

\section{SPECIES LIST AND TAXONOMIC NOTES}

The following alphabetical list includes bibliographic references to all the taxa recorded in this study, and some additional observations about the mor- phological limits applied to some species. Literature references include the original description and my present concept of the species. One new form, Eucyrtidium sp., is described but not named.

Artophormis gracilis Riedel, 1959, p. 300, pl. 2, figs. 12-13. Riedel and Sanfilippo, 1970, p. 532, pl. 13, fig. 6; 1971, pl. 3B, figs. 5-7, pl. 3B, figs. 57 , pl. 6 , fig. 7 .

Calocycletta (Calocyclior) caepa Moore, 1972, p. 150, pl. 2, figs. 4-7.

Calocycletta (Calocyclissima) costata (Riedel). Calocyclas costata Riedel, 1959, p. 296, pl. 2, fig. 9. Calocycletta costata (Riedel), Riedel and Sanfilippo, 1970, p. 535, pl. 14, fig. 12.

Calocycletta robusta Moore, 1971, p.743, p.10, figs. 5-6.

Calocycletta (Calocyclopsis) serrata Moore, 1972, p. 148, pl. 2, figs. 1-3.

Calocycletta (Calocycletta) virginis (Haeckel). Calocyclas (Calocycletta) virginis Haeckel, 1887, p. 1381, pl. 74, fig. 4; Riedel, 1959, p. 295, pl. 2, 


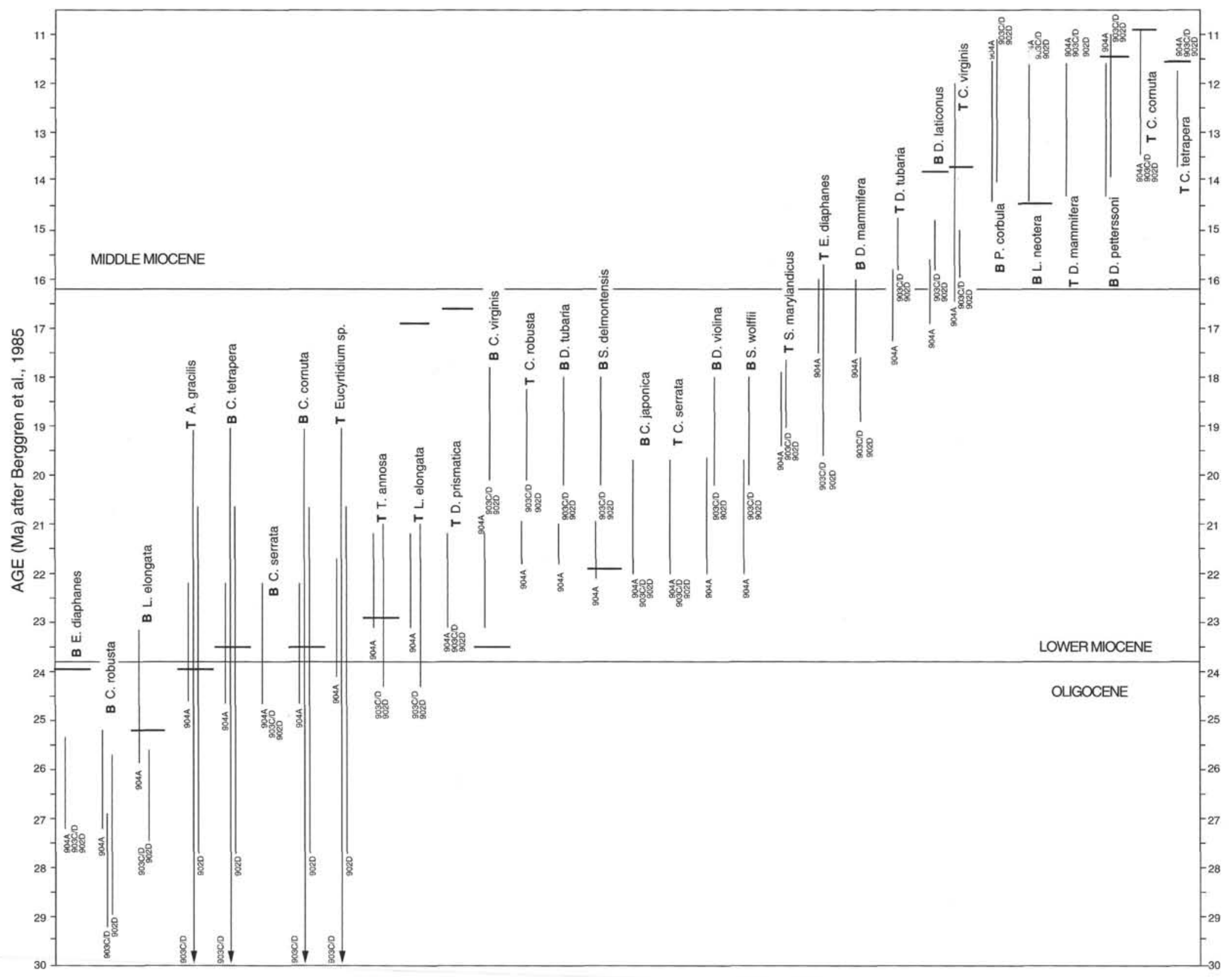




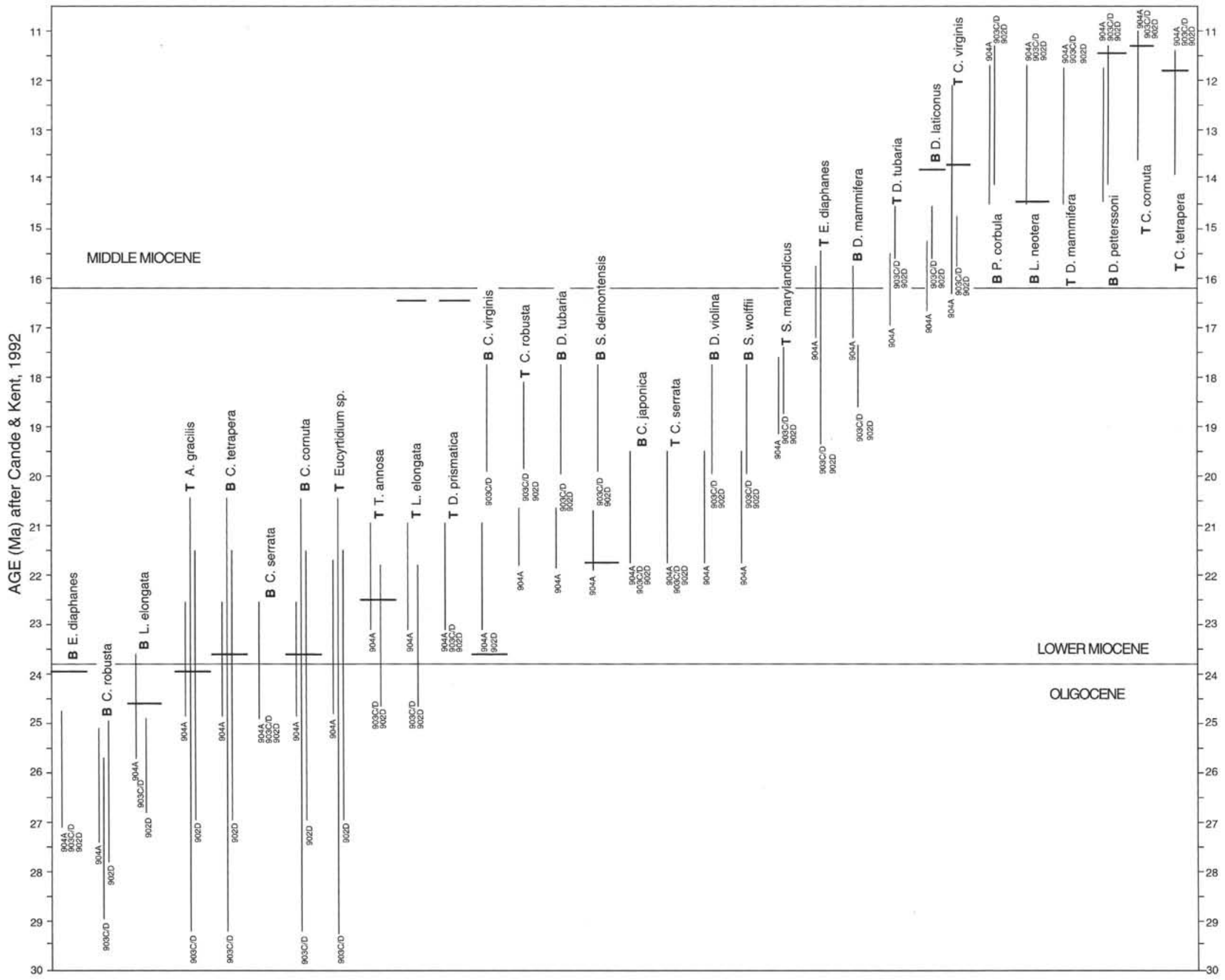

Figure 3. Vertical lines represent calculated age ranges (using Cande and Kent, 1992) for radiolarian events in Holes 902D, 903C/D, and 904A, based on Sr-isotope analyses. Horizontal bars depict ages from other sources (see Table 4). $\mathrm{T}$ = last morphotypic occurrence; $\mathrm{B}=$ first morphotypic occurrence. 
fig. 8. Calocycletta virginis Haeckel, Riedel, and Sanfilippo, 1970, p. 535, pl. 14, fig. 10. This species (Pl. 1, fig. 4) is distinctive, but can only be recognized unambiguously when the terminal lamellar feet can be seen. Hence, in poorly preserved material, such as was found in Holes 903C/D, it is an unreliable marker species.

Cyrtocapsella cornuta (Haeckel). Cyrtocapsa (Cyrtocapsella) cornuta Haeckel, 1887, p. 1513, pl. 78, fig. 9. Cyrtocapsella cornuta Haeckel, Sanfilippo and Riedel, 1970, p. 453, pl. 1, figs. 19-20 (with synonymy).

Cyrtocapsella japonica (Nakaseko). Eusyringium japonicum Nakaseko, 1963, p. 193, pl. 4, figs. 1-3. Cyrtocapsella japonica (Nakaseko), Sanfilippo and Riedel, 1970, p. 452, pl. 1, figs. 13-15. Forms encountered herein (Pl. 1, fig. 3) are generally more robust than the tropical forms. The morphotypic first occurrence of this species is much older than has been reported previously.

Cyrtocapsella tetrapera (Haeckel). Cyrtocapsa (Cyrtocapsella) tetrapera Haeckel, 1887, p. 1512, pl. 78, fig. 5. Cyrtocapsella tetrapera Haeckel, Sanfilippo and Riedel, 1970, p. 453, pl. 1, figs. 16-18 (with synonymy).

Diartus petterssoni (Riedel and Sanfilippo). Cannartus (?) petterssoni conditional manuscript name proposed in Riedel and Funnell, 1964, p. 310; Riedel and Sanfilippo, 1970, p. 520, pl. 14, fig. 3. Diartus petterssoni (Riedel and Sanfilippo), Sanfilippo and Riedel, 1980, p. 1010.

Didymocyrtis antepenultima (Riedel and Sanfilippo). Panarium antepenultimum conditional manuscript name proposed by Riedel and Funnell, 1964, p. 311. Ommatartus antepenultimus Riedel and Sanfilippo, 1970, p. 521, pl. 14, fig. 4. Didymocyrtis antepenultima (Riedel and Sanfilippo), Sanfilippo and Riedel, 1980, p. 1010.

Didymocyrtis (?) bassanii (Carnevale). Cannartidium bassanii in Carnevale, 1908, p. 21, pl. 3, fig. 12. Didymocyrtis (?) bassanii (Carnevale), Sanfilippo and Riedel, 1980, p. 1011.

Didymocyrtis laticonus (Riedel). Cannartus laticonus Riedel, 1959, p. 291, pl. 1, fig. 5. Didymocyrtis laticonus (Riedel), Sanfilippo and Riedel, 1980, p. 1010 .

Didymocyrtis mammifera (Haeckel). Cannartidium mammiferum Haeckel, 1887, p. 375 , pl. 39, fig. 16. Cannartus mammiferus (Haeckel), Riedel, 1959, p. 291, pl. 1, fig. 4. Cannartus mammifer (Haeckel), Sanfilippo et al., 1973, p. 216, pl. 1, fig. 7. Didymocyrtis mammifera (Haeckel), Sanfilippo and Riedel, 1980, p. 1010.

Didymocyrtis prismatica (Haeckel). Pipettella prismatica Haeckel, 1887, p. 305, pl. 39, fig. 6; Riedel, 1959, p. 287, pl. 1, fig. 1. Cannartus prismaticus (Haeckel), Riedel and Sanfilippo, 1970, pl. 15, fig. 1. Didymocyrtis prismatica (Haeckel), Sanfilippo and Riedel, 1980, p. 1010.

Didymocyrtis tubaria (Haeckel). Pipettaria tubaria Haeckel, 1887, p. 339, pl. 39, fig. 15. Cannartus tubarius (Haeckel), Riedel, 1959, p. 289, pl. 1, fig. 2. Didymocyrtis tubaria (Haeckel), Sanfilippo and Riedel, 1980, p. 1010.

Didymocyrtis violina (Haeckel). Cannartus violina Haeckel, 1887, p. 358, pl. 39, fig. 10; Riedel, 1959, p. 290, pl. 1, fig. 3 (with synonymy). Didymocyrtis violina (Haeckel), Sanfilippo and Riedel, 1980, p. 1010.

Dorcadospyris ateuchus (Ehrenberg). Ceratospyris ateuchus Ehrenberg 1873, pl. 218; 1875, pl. 21, fig. 4D. Dorcadospyris ateuchus (Ehrenberg), Riedel and Sanfilippo, 1970, p. 523, pl. 15, fig. 4. Dorcadospyris (?) or Petalospyris (?) ateuchus (Ehrenberg), Petrushevskaya and Kozlova, 1972, p. 532.

Dorcadospyris dentata Haeckel, 1887, p. 1040, pl. 85, fig. 6; Riedel, 1957, p. 79, pl. 1, fig. 4; Riedel and Sanfilippo, 1971, pl. 2D, figs. 2-3.

Eucyrtidium diaphanes Sanfilippo and Riedel. Calocyclas coronata Carnevale, 1908, p. 33, pl. 4, fig. 24 (non Eucyrtidium coronatum Ehrenberg, 1873). Eucyrtidium diaphanes Sanfilippo and Riedel, Sanfilippo et al., 1973, p. 221, pl. 5, figs. 12-14 (new name). A single row of enlarged pores on the proximal part of the abdomen is characteristic of this species (Pl. 1, fig. 10). However, these pores, the thoracic pores, and the rest of the abdominal pores are more irregular in size and arrangement in middle latitude forms than they are in low latitude specimens.

\section{Eucyrtidium sp.}

\section{(Pl. 1, Figs. 7-9)}

Description: Multisegmented form with up to 6 segments, approximately conical in outline. Shell wall heavy. Simple cephalis, poreless, hyaline with apical spine free within cephalis and projecting as a short cylindrical apical horn. Collar and subsequent strictures distinct. Thorax and subsequent segments inflated, increasing in breadth distally. Pores subcircular, in longitudinal rows on the thorax and abdomen, but becoming irregular in size and arrangement distally. Termination ragged. In some specimens the final segment is constricted distally.
Dimensions (based on 10 specimens): Length: cephalis $25-30 \mu \mathrm{m}$; thorax 30-35 $\mu \mathrm{m}$; abdomen 43-55 $\mu \mathrm{m}$; maximum 195-265 $\mu \mathrm{m}$. Breadth: cephalis $25-$ $30 \mu \mathrm{m}$; thorax 55-70 $\mu \mathrm{m}$; abdomen 87-112 $\mu \mathrm{m}$; maximum 105-133 $\mu \mathrm{m}$.

Remarks: It is possible that this form is the ancestor of Stichocorys delmontensis.

Lithopera (Lithopera) neotera Sanfilippo and Riedel, 1970, p. 454, pl. 1, figs. 24-26, 28.

Lychnocanoma elongata (Vinassa de Regny). Tetrahedrina elongata Vinassa de Regny, 1900, p. 243, pl. 2, fig. 31. Lychnocanium bipes Riedel, 1959 , p. 294, pl. 2, figs. 5-6. Lychnocanoma elongata (Vinassa de Regny), Sanfilippo et al., 1973, p. 221, pl. 5, figs. 19-20 (with synonymy).

Phormostichoartus corbula (Harting). Lithocampe corbula Harting, 1863, p. 12, pl. 1, fig. 21. Phormostichoartus corbula (Harting), Nigrini, 1977, p. 252 , pl. 1, fig. 10 (with synonymy).

Spongasteriscus marylandicus Martin. Spongasteriscus marylandicus Martin, 1904, p. 453, pl. 130, fig. 10; Palmer, 1986, p. 28, pl. 1, fig. 2. This form ( $\mathrm{Pl}$. 1, figs $1-2)$ is distinctive even in poorly preserved material and is a useful lower Miocene stratigraphic marker species.

Stichocorys delmontensis (Campbell and Clark). Eucyrtidium delmontense Campbell and Clark, 1944, p. 56, pl. 7, figs. 19-20. Stichocorys delmontensis (Campbell and Clark), Sanfilippo and Riedel, 1970, p. 451, pl. 1, fig. 9 (with synonymy). Forms encountered herein (Pl. 1, figs. 5-6) always have heavier shell walls than the typical tropical specimens. The specimen figured in Plate 1, figure 6, is an early form in which the abdomen is shorter, difference in breadth between the third and subsequent segments is less pronounced, and the abdominal pores are irregular.

Stichocorys wolffii Haeckel, 1887, p. 1479, pl. 80, fig. 10; Riedel, 1957, p. 92, pl. 4 , figs. 6-7.

Theocorys spongoconus Kling, 1971, p. 1087, pl. 5, fig. 6.

Theocyrtis annosa (Riedel). Phormocyrtis annosa Riedel, 1959, p. 295, pl. 2, fig. 7. Theocyrtis annosa (Riedel), Riedel and Sanfilippo, 1970, p. 535.

Tristylospyris triceros (Ehrenberg). Ceratospyris triceros Ehrenberg, 1873, p. 220; 1875, pl. 21, fig. 5. Tristylospyris triceros (Ehrenberg), Haeckel, 1887, p. 1033; Riedel, 1959, p. 292, pl. 1, figs. 7-8.

\section{SUMMARY}

Analysis of the radiolarian fauna in three sites $(902,903$, and 904) drilled on the New Jersey Margin has resulted in the placement of 31 biostratigraphic "events" (morphotypic first and last occurrences) ranging in age from the late Oligocene to the middle Miocene. For the most part, the standard tropical radiolarian zonation of Riedel and Sanfilippo $(1971,1978)$ could be applied, despite the lack of zonal markers in much of the lower Miocene section. The radiolarian "events" could be placed in the context of absolute ages derived from strontium isotope analyses of mixed foraminifer species to give an age range for each event. Comparison of these age ranges with those determined in other parts of the world ocean shows that most of the events are globally synchronous within the error limits of the age and stratigraphic data. However, three events show marked diachrony. The last occurrences of $L$. elongata and D. prismatica and the first occurrence of $C$. japonica are all much older in the New Jersey Margin material. Because L. elongata is known to prefer warmer waters, its premature extinction in this area suggests cooling of at least the local water mass at about $20 \mathrm{Ma}$.

\section{ACKNOWLEDGMENTS}

Research for this paper was funded by a grant from USSAC. Members of the shipboard party have been generous in their collaboration with the author. Their "welcome aboard" spirit, particularly during the post-cruise meeting in Oxford, was appreciated. The author also wishes to thank Dr. Annika Sanfilippo for useful discussions throughout the preparation of this paper and for expert assistance with the photographs. The bibliography was prepared using RadRefs, a comprehensive computer database of all radiolarian literature. 


\section{REFERENCES}

Berggren, W.A., Kent, D.V., Flynn, J.J., and Van Couvering, J.A., 1985. Cenozoic geochronology. Geol. Soc. Am. Bull., 96:1407-1418.

Campbell, A.S., and Clark, B.L., 1944. Miocene radiolarian faunas from Southern California. Spec. Pap.-Geol. Soc. Am., 51:1-76.

Cande, S.C., and Kent, D.V., 1992. A new geomagnetic polarity time scale for the Late Cretaceous and Cenozoic. J. Geophys. Res., 97:1391713951.

Carnevale, P., 1908. Radiolarie e silicoflagellati di Bergonzano (Reggio Emilia). Mem. R. Istit. Veneto Sci. Lett. Arti, 28:1-46.

Ehrenberg, C.G., 1873. Grössere Felsproben des Polycystinen-Mergels von Barbados mit weiteren Erläuterungen. K. Preuss. Akad. Wiss. Berlin, Monatsber., 1873, 213-263.

, 1875. Fortsetzung der mikrogeologischen Studien als GesammtUebersicht der mikroskopischen Paläontologie gleichartig analysirter Gebirgsarten der Erde, mit specieller Rücksicht auf den PolycystinenMergel von Barbados. Abh. K. Akad. Wiss. Berlin, Jahre 1875:1-225.

Haeckel, E., 1887. Report on the Radiolaria collected by H.M.S. Challenger during the years 1873-1876. Rep. Sci. Results Voy. H.M.S. Challenger, 1873-1876, Zool., 18:1-1803.

Harting, P., 1863. Bijdrage tot de kennis der mikroskopische fauna en flora van de Banda-Zee (Contribution to the knowledge of microscopic fauna and flora from the Banda Sea). Verhandel., K. Akad. Wetensch., Amster. dam, 10:1-34.

Hodell, D.A., and Woodruff, 1994. Variations in the strontium isotopic ratio of seawater during the Miocene: stratigraphic and geochemical implications. Paleoceanography, 9:405-426.

Johnson, D.A., and Nigrini, C.A., 1985. Synchronous and time-transgressive Neogene radiolarian datum levels in the equatorial Indian and Pacific Oceans. Mar. Micropaleontol., 9:489-523.

Kling, S.A., 1971. Radiolaria: Leg 6 of the Deep Sea Drilling Project. In Fischer, A.G., Heezen, B.C., et al., Init. Repts. DSDP, 6: Washington (U.S. Govt. Printing Office), 1069-1117.

Martin, G.C., 1904. Radiolaria. In Clark, W.B., Eastman, C.R., Glenn, L.C., Bagg, R.M., Bassler, R.S., Boyer, C.S., Case, E.C., and Hollick, C.A. (Eds.), Systematic Paleontology of the Miocene Deposits of Maryland: Baltimore (Maryland Geol. Surv., Johns Hopkins Press), 447-459.

Moore, T., 1971. Radiolaria. In Tracey, J.I., Jr., Sutton, G.H., et al., Init. Repts. DSDP, 8: Washington (U.S. Govt. Printing Office), 727-775.

, 1972. Mid-Tertiary evolution of the radiolarian genus Calocycletta. Micropaleontology, 18:144-152.

Nakaseko, K., 1963. Neogene Cyrtoidea (Radiolaria) from the Isozaki Formation in Ibaraki Prefecture, Japan. Sci. Rep., Coll. Gen. Educ., Osaka Univ., 12:165-198.

Nigrini, C., 1977. Tropical Cenozoic Artostrobiidae (Radiolaria). Micropaleontology, 23:241-269.
1985. Radiolarian biostratigraphy in the central equatorial Pacific, Deep Sea Drilling Project Leg 85. In Mayer, L., Theyer, F., Thomas, E., et al., Init. Repts. DSDP, 85: Washington (U.S. Govt. Printing Office), 511-551.

Palmer, A., 1986. Miocene radiolarian biostratigraphy, U.S. mid-Atlantic Coastal Plain. Micropaleontology, 32:19-31.

Petrushevskaya, M.G., and Kozlova, G.E., 1972. Radiolaria, Leg 14, Deep Sea Drilling Project. In Hayes, D.E., Pimm, A.C., et al., Init. Repts. DSDP, 14: Washington (U.S. Govt. Printing Office), 495-648.

Riedel, W.R., 1957. Radiolaria: a preliminary stratigraphy. In Petterson, H. (Ed.), Rep. Swed. Deep-Sea Exped., 1947-1948 (Vol. 6): Goteborg (Elanders Boktryckeri Aktiebolag), 59-96.

, 1959. Oligocene and Lower Miocene Radiolaria in tropical Pacific sediments. Micropaleontology, 5:285-302.

Riedel, W.R., and Funnell, B.M., 1964. Tertiary sediment cores and microfossils from the Pacific Ocean floor. Q. J. Geol. Soc. London, 120:305368.

Riedel, W.R., and Sanfilippo, A., 1970. Radiolaria, Leg 4, Deep Sea Drilling Project. In Bader, R.G., Gerard, R.D., et al., Init. Repts. DSDP, 4: Washington (U.S. Govt. Printing Office), 503-575.

1971. Cenozoic Radiolaria from the western tropical Pacific, Leg 7. In Winterer, E.L., Riedel, W.R., et al., Init. Repts. DSDP, 7 (Pt. 2): Washington (U.S. Govt. Printing Office), 1529-1672.

, 1978. Stratigraphy and evolution of tropical Cenozoic radiolarians. Micropaleontology, 24:61-96.

Sanfilippo, A., Burckle, L.H., Martini, E., and Riedel, W.R., 1973. Radiolarians, diatoms, silicoflagellates and calcareous nannofossils in the Mediterranean Neogene. Micropaleontology, 19:209-234.

Sanfilippo, A., and Nigrini, C., 1995. Radiolarian stratigraphy across the Oligocene/Miocene transition. Mar. Micropaleontol., 24:239-285.

, in press. Radiolarian biomarkers at the Oligocene/Miocene boundary. Conf. Vol., ODP and the Marine Biosphere, Aberystwyth, Wales, April 1994.

Sanfilippo, A., and Riedel, W.R., 1970. Post-Eocene "closed" theoperid radiolarians. Micropaleontology, 16:+46-462.

, 1980. A revised gener $z$ and suprageneric classification of the Artiscins (Radiolaria). J. Paleontol., 54:1008-1011.

Sanfilippo, A., Westberg-Smith, M.J., and Riedel, W.R., 1985. Cenozoic radiolaria. In Bolli, H.M., Saunders, J.B., and Perch-Nielsen, K. (Eds.), Plankton Stratigraphy: Cambridge (Cambridge Univ. Press), 631-712.

Vinassa de Regny, P.E., 1900. Radiolari Miocenici Italiani. Mem. R. Acad. Sci. Inst. Bologna, Ser. 5, 8:227-257.

Date of initial receipt: 2 March 1995

Date of acceptance: 24 August 1995

Ms 150SR-006 


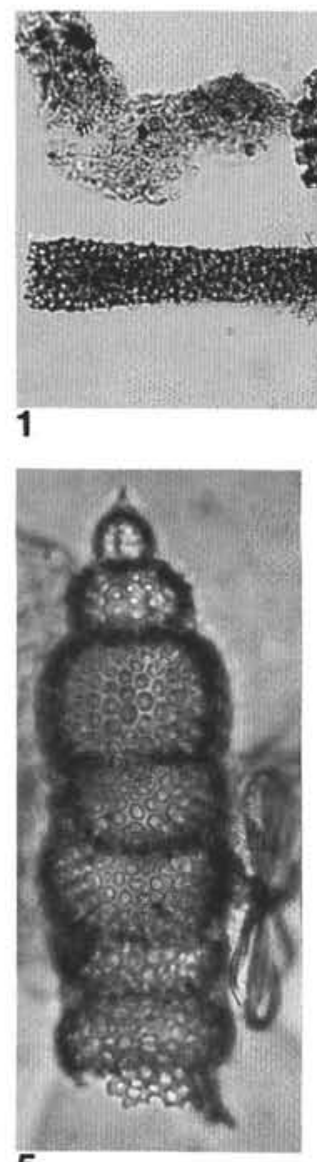

5

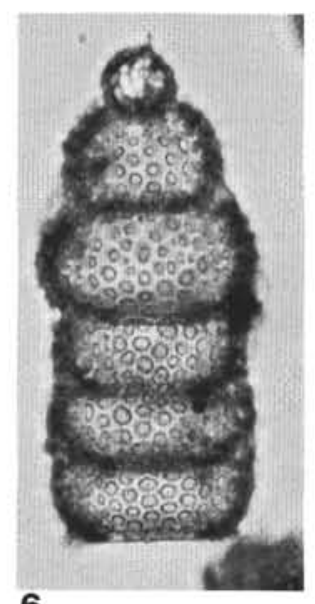

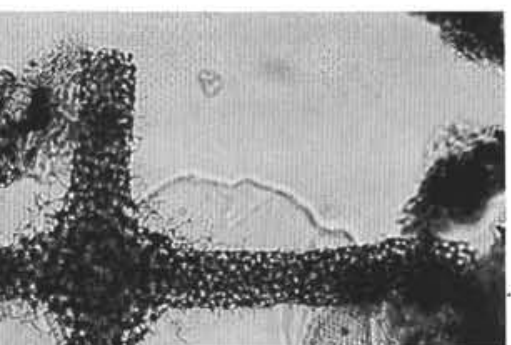
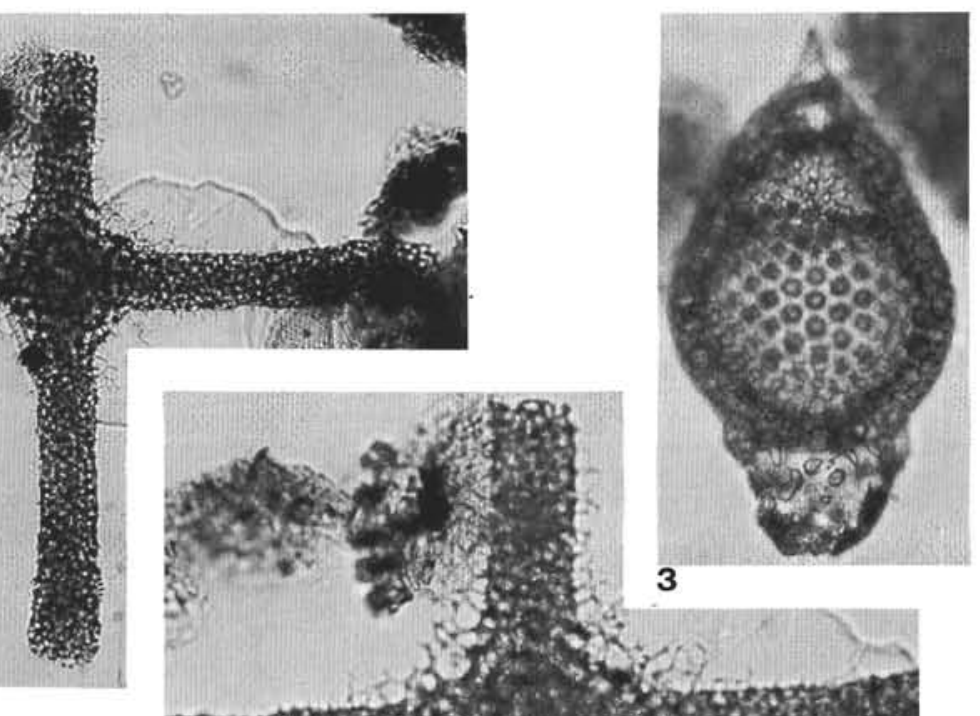

3
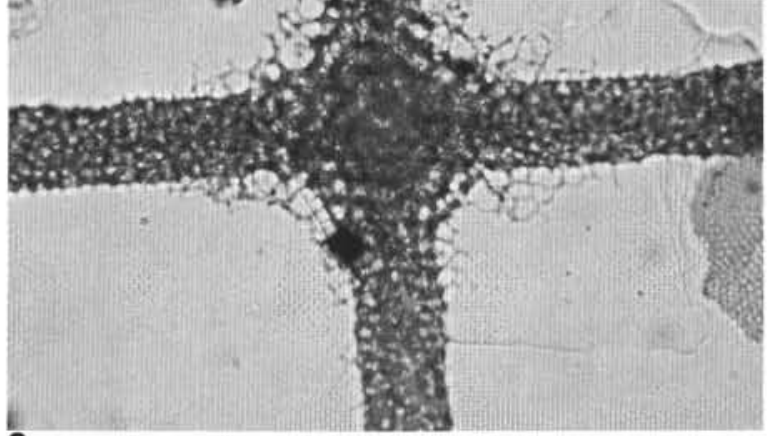

2

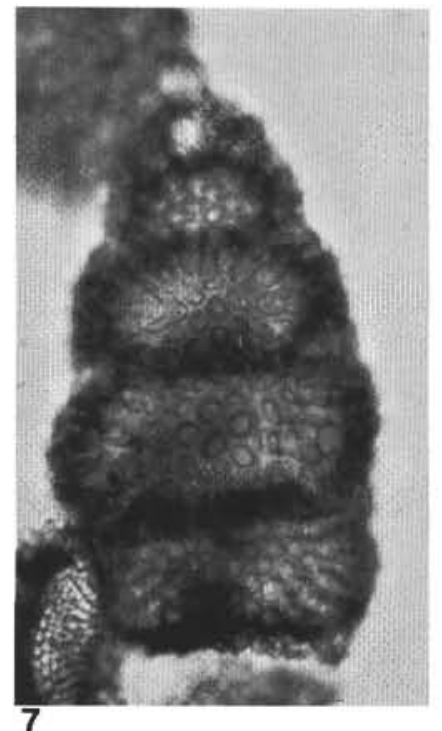

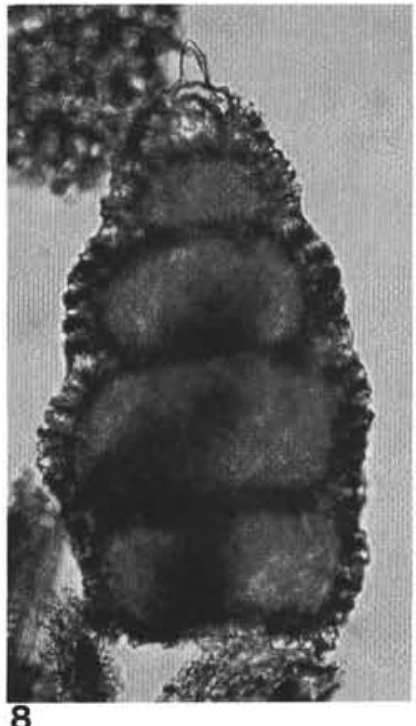

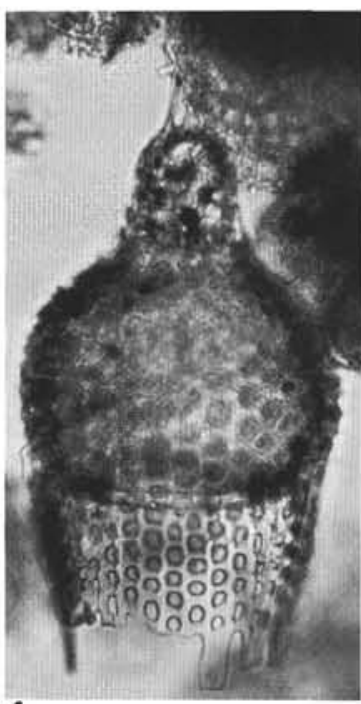

4
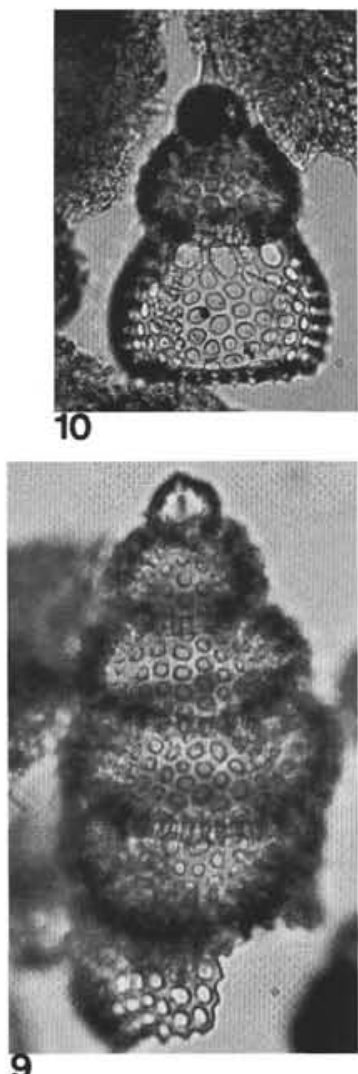

Plate 1. All figures $\times 275$ unless otherwise noted. 1. Spongasteriscus marylandicus Martin. Sample 150-904A-33X-6. R-V17/1, $\times 195$. 2. Spongasteriscus marylandicus Martin showing details of central structure. Sample 150-904A-33X-6, 60-62 cm, R-V17/1. 3. Cyrtocapsella japonica (Nakaseko) showing more robust form typical of the studied area. Sample 150-902D-36X-3, 60-62 cm, V41/0. 4. Calocycletta (Calocycletta) virginis (Haeckel) showing diagnostic terminal feet. Sample 150-904A-31X-6, 66-62 cm, P31/0. 5. Stichocorys delmontensis (Campbell and Clark). Sample 150-904A-15H-6, 60-62 cm, M31/0. 6. Stichocorys delmontensis (Campbell and Clark). Early form in which the abdomen is generally shorter, difference in breadth between the third and subsequent segments is not as pronounced, and the abdominal pores are irregularly arranged. Sample 150-904A-31X-6, 60-62 cm, B-L24/3. 7. Eucyrtidium sp., focused on abdominal and post-abdominal pores. Sample 150-904A-33X-6, R-V17/1. 8. Eucyrtidium sp., focused on apical horn. Sample 150-904A-33X-6, R-V17/1. 9. Eucyrtidium sp., Sample 150-904A-34X-2, F34/1, 10. Eucyrtidium diaphanes Sanfilippo and Riedel, Sample 150-904A-36X-6, 60-62 cm, Q26/2. 